\title{
The Future Is Now: Esports Policy Considerations and Potential Litigation
}

\author{
John T. Holden \\ Florida State University
}

\author{
Anastasios Kaburakis \\ Saint Louis University
}

\section{Ryan Rodenberg \\ Florida State University}

\begin{abstract}
Competitive video gaming is rapidly gaining mainstream attention. Major U.S. television networks have commenced broadcasting such competitions. The term esports has been assigned to the practice, but it remains to be seen whether lawmakers and regulators agree that the contests are indeed sports. This paper provides a comprehensive examination, analysis, and application of the tests that have previously been used to determine whether an activity is a sport. We illustrate potential streams of litigation, some of which are specific to activities classified as sport. The emergence of esports in the United States has highlighted the absence of a legal definition of sport. Be it the newest form of sport or not, esports afford a glimpse to the future of creative competition, business innovation, and the related legal, policy, and litigation implications emerging alongside this new (sporting or otherwise competitive) activity.
\end{abstract}

Keywords: esports law; competitive sport tests application; gambling policy, skins wagering and corruption prevention; gaming litigation forecast

Competitive video gaming has become one of the quickest-growing segments of the entertainment industry. ${ }^{1}$ Esports, as the practice of competitive video gaming has been named, is a term that represents a variety of different game types and game titles. ${ }^{2}$ Deloitte estimated that esports would generate global revenues of $\$ 500$ million in 2016, increasing by $25 \%$ in ensuing years. ${ }^{3}$ Projections extending to 2019 forecast direct esports revenue surpassing the $\$ 1$ billion mark. ${ }^{4}$ Parshakov and Zavertiaeva noted that more than 70 million people watched various esports tournaments in $2013 .{ }^{5}$

As esports' growth continues, the industry is beginning to face a multitude of potential challenges. While some problems - including match-fixing and dopinghave been well documented, others, such as issues of diversity, are slowly becoming

Holden and Rodenberg are with the Dept. of Sport Management, Florida State University, Tallahassee. Kaburakis is with the Dept. of Management, Saint Louis University, Saint Louis, MO. Address author correspondence to Anastasios Kaburakis at kaburakis@slu.edu 
more prominent. ${ }^{6}$ The current regulatory landscape surrounding esports is uncertain. In many respects, how esports continue to grow in the United States will depend on how the activity is classified. Political actors, regulators, industry stakeholders, educators, and, eventually, courts need to address the normative question most competitive activities deal with at their nascent stage: Are esports "sports" in the traditional athletic sense? Or are video game competitions more closely aligned with professional wrestling and other types of performing arts ${ }^{7}$ and/or skill-based entertainment? ${ }^{8}$

Video game tournaments are in fact about 20 years old; however, their recent explosive growth is largely connected to the launch of Twitch, an online streaming platform, which now rivals major entertainment sites for online traffic. ${ }^{9}$ The rise of video game streaming eliminated the need for national television contracts and opened up access to competitive video gaming without regard for geographic constraints. As such, one would assume that esports' business evolution and regulatory trajectory are markedly different from traditional mainstream sports. However, at the dawn of 2017, ample legal issues surrounding esports are evident, including labor, employment conditions, equal opportunity, competition, governance, corruption, intellectual property, as well as several areas of contract and tort law.

This paper provides three meaningful contributions to the literature. First, we discuss what esports are and suggest that esports competitors are likely closer to professional athletes than to the perpetuated stereotype of video games being played by overweight teenagers huddled in dark basements. Second, we provide a comprehensive examination of how esports may be evaluated by courts or administrative agencies with regard to whether or not the activity qualifies as a sport. Third, we address recent litigation impacting esports and highlight that, should esports take a similar trajectory to traditional sports, the future will likely feature a multitude of litigation in a number of different areas. Addressing whether esports is a sport could have a meaningful impact on the application of a variety of different federal and state laws; however, regardless of whether esports are a sport, competitive gaming has established a presence in the United States, and that presence will inevitably collide with a number of different policies and laws at both the state and federal levels.

\section{What Is an Esport?}

Coates and Parshakov observed that esports have no common definition, but noted that Wagner defined the activity as "an area of sport activities in which people develop and train mental or physical abilities in the use of information and communication technologies. ${ }^{10}$ Hamari and Sjöblom described esports "as a form of sports where the primary aspects of the sport are facilitated by electronic systems; the input of players and teams as well as the output of the esports system are mediated by human-computer interfaces." 11 Hamari and Sjöblom furthered their description, noting that the term esports "commonly referred to competitive (pro and amateur) video gaming that is often coordinated by different leagues, ladders and tournaments, where players customarily belong to teams or other 'sporting' organizations who are sponsored by various business organizations." 12

Hewitt noted that esports face a challenge in their acceptance as mainstream sports. ${ }^{13}$ Esports provide a competitive environment without individuals being 
confined by their own physicality. ${ }^{14}$ Hewitt argued that as video games have developed, they have incorporated increasing levels of skill, allowing for exceptional players to be differentiated from the average masses. ${ }^{15}$ Certain video games have historically attracted skilled players, but more recently specific titles appear to have been developed specifically for competitive play. ${ }^{16}$ While both traditional sports and esports display feats of skill, live spectating of an esports event involves watching a monitor or screen with game play footage and not the human participants. ${ }^{17}$

Like traditional athletes, professional video game players are members of teams that "are responsible for their training, sponsorships, travel and lodging when playing abroad," with some teams even providing team housing when not traveling. ${ }^{18}$ Carvalho observed that it should be worth considering individual games as distinctive sports, as each game for which competitive events take place are distinct, just as basketball and baseball are distinct and both are recognized as sports. ${ }^{19}$ Carvalho noted that the traditional physical location model often associated with sports is not present or even necessary in the esports model, as there is no necessity to create billion-dollar stadiums. ${ }^{20}$ Additionally, Carvalho stated there are several differences in the makeup of the esports business structure-for example, there is no sharing of broadcast revenues among teams, and teams are largely reliant on sponsorships to provide for their players. ${ }^{21}$ With the advent of more diverse revenue sources, consistent revenue and gaming markets' growth, and more outlets for professional players and teams to engage in this fledgling industry, the latter may rely less on sponsorships, despite the fact that projections estimate esports brands' spending to more than double by 2020 , surpassing $\$ 800$ million. $^{22}$

Carter and Gibbs noted that esports are a "physically draining, expertise driven activity which hinges on performance in both the physical and digital domains." 23 Hollist defined esports as "professional video game matches where players compete against other players before an audience." 24 Hollist also noted that competitive video gaming comprises many different forms similar to different sports. ${ }^{25}$ The question of whether esports are sports is potentially a double-edged sword. As will be discussed in the ensuing sections and summarized in Table 1, there is a wide variety of potential tests that could be applied by agencies or courts to determine which activities constitute a sport.

\section{Are Esports a Sport?}

The question of whether esports are a sport is legally meaningful. The United States has a variety of statutes that are only applicable to occurrences involving sport. ${ }^{26}$ Sports have received special treatment at the federal level for an extensive period of time. Indeed, as far back as at least 1888, members of Congress were requesting that certain sports be specifically referenced in legislation. ${ }^{27}$ Professor Dionne Koller has observed that some federal sport-specific statutes, such as the Sports Broadcasting Act, "are aimed at facilitating the growth and protecting the integrity of professional sports," ${ }^{28}$ whereas other statutes, such as the Professional Boxing Safety Act, are meant to provide a level of uniform regulation. ${ }^{29}$ Indeed, Professor Gabe Feldman described the way that sport is treated by the law in the United States as "unique." 30 Sport-specific statutes may present both advantages and disadvantages for emerging activities such as esports. For instance, while stakeholders may benefit from the protections associated with the Sports Bribery 
Table 1 Tests to Determine Whether Esports Are a Sport

\begin{tabular}{|c|c|}
\hline \multicolumn{2}{|l|}{ Are esports a sport? } \\
\hline Test application & Esports applicability \\
\hline \multicolumn{2}{|l|}{ Lüschen 1970-Nafziger 1988} \\
\hline a. Cooperation & $\mathrm{Y}$ \\
\hline b. Association & $\mathrm{Y}$ \\
\hline c. Contest & $\mathrm{Y}$ \\
\hline \multicolumn{2}{|l|}{ Slusher 1973} \\
\hline a. Rules for creation & $\mathrm{Y}$ \\
\hline b. Rules make game appealing to audience & Y \\
\hline c. Fills an unfulfilled need for activity & $\mathrm{Y}$ \\
\hline \multicolumn{2}{|l|}{ Michelman 2000} \\
\hline a. Public perception of the activity & - \\
\hline \multicolumn{2}{|l|}{ Wasserman 2008} \\
\hline a. Large motor skills & $\mathrm{N}$ \\
\hline b. Simple machines only & $\mathrm{N}$ \\
\hline c. Objective scoring & $\mathrm{Y}$ \\
\hline d. Competition among participants & $\mathrm{Y}$ \\
\hline \multicolumn{2}{|l|}{ Lakier 2014} \\
\hline a. Function is to entertain rather than educate or politicize & $\mathrm{Y}$ \\
\hline b. Inherent feature that renders it inexpressive & $\mathrm{Y}$ \\
\hline c. Competitive activity & $\mathrm{Y}$ \\
\hline \multicolumn{2}{|l|}{ Guttman 1978} \\
\hline a. Play & $\mathrm{Y}$ \\
\hline b. A set of rules & $\mathrm{Y}$ \\
\hline c. Determination of winner and loser & $\mathrm{Y}$ \\
\hline d. Skillful and strategic use of one's body & - \\
\hline \multicolumn{2}{|l|}{ Suits 2007} \\
\hline a. Defined set of rules & $\mathrm{Y}$ \\
\hline b. Requires skill & $\mathrm{Y}$ \\
\hline c. Requires physical skill & - \\
\hline d. Has broad appeal & Y \\
\hline e. Achieved institutional stability & - \\
\hline \multicolumn{2}{|l|}{ Jackiw's adapted dictionary definitions 2014} \\
\hline a. Physical activity & - \\
\hline b. For diversion, recreation, or pleasure & $\mathrm{Y}$ \\
\hline c. Involving skill & $\mathrm{Y}$ \\
\hline d. Competition & $\mathrm{Y}$ \\
\hline \multicolumn{2}{|l|}{ U.S. code-created criteria } \\
\hline a. Established eligibility criteria by a governing association & Y \\
\hline b. Between individual contestants or teams of contestants & $\mathrm{Y}$ \\
\hline c. Events are announced to the public before commencement & $\mathrm{Y}$ \\
\hline
\end{tabular}

(continued) 
Arguments submitted as part of the Biediger v. Quinnipiac litigation

American Association of Cheerleading Coaches

a. Physical activity propelling or overcoming a mass through space $\mathrm{N}$

b. Competing against an opponent

c. Uniform set of rules to determine a winner

$\mathrm{Y}$

d. Primary purpose being comparison of skills

Y

Quinnipiac University argument

a. Operating budget comparable to other teams

b. Comparable benefits and services

Y

Y

i. Equipment

ii. Medical treatment

iii. Study halls

iv. Community service opportunities

c. Comparable coaching staff

d. Recognition

USA amicus brief

a. Allow for receiving same benefits as other athletes

Y

b. Comparable program structure and administration

Y

c. Comparable team preparation and competition

$\mathrm{Y}$

d. Post-season events

Y

e. Athletic competition is the primary purpose

Y

April 11, 2000, OCR letter in Quinnipiac reply brief

a. Selection of team based on objective athletic ability $\quad Y$

b. Defined season

c. Comparable preparation and competition

Y

i. Coaching

ii. Recruitment

iii. Budget

iv. Tryouts

v. Eligibility

vi. Comparable practice sessions

vii. Competitive opportunities

d. The activity is administered by a governing body

e. Primary purpose of the activity is athletic competition

Y

Y

OCR Dear Colleague letter

a. Team selection based on athletic ability

b. Activity is limited to a defined season

Y

Y

c. Athletic department (governing body) administers the activity

Y

d. Primary purpose of activity is competition

$\mathrm{Y}$

e. Does team prepare for competition like other teams?
i. Coaching
ii. Budget
iii. Tryouts
iv. Eligibility
v. Practice
vi. Competitive opportunities
vii. Recognition

Note. Y represents yes; $\mathrm{N}$ represents no; - represents unclear. 
Act, ${ }^{31}$ if esports are considered to be a sport, the application of the Wire $\mathrm{Act}^{32}$ or Professional and Amateur Sports Protection $\mathrm{Act}^{33}$ may hinder the growth of the complementary gambling market. While some countries, such as France, have taken affirmative steps to classify esports as a sport, the question of esports' status in the United States, in particular at the federal level, is very much unresolved. ${ }^{34}$ There are a variety of different tests that a court or administrative agency may use to analyze whether esports are a sport. While it is possible that there could be a proclamation or memorandum opinion issued by the Department of Justice clarifying the activity's status, it may be more likely that a court will be tasked with determining the status of esports. ${ }^{35}$ The following sections detail different tests that can help determine which activities can be classified as sports. These tests could also be utilized by a court to determine the status of esports.

\section{The Lüschen and Nafziger Test}

Utilizing the Olympic Charter's most recent (August 2016) iteration, sanctioned sports to be considered for inclusion in the Olympic Games are evaluated by several criteria-for example, the value added to the Olympic movement (including business model-specific considerations such as targeted additional revenues) and institutional matters, alongside the popularity of each sport. ${ }^{36}$ Professor James Nafziger noted that international sport competition is ever fluid and constantly evolving. He remarked that sporting competitions cannot be stagnant or preserved as some archaic ritual, a duty, a routine, which everyone has to go through; instead, he expressed his observation that Olympic competitions keep evolving. ${ }^{37}$ Nafziger posited three important elements for sporting competitions: cooperation, association, and contest. ${ }^{38}$ Esports satisfy all three prerequisites: (a) there is cooperation among participants and teams created for esports competitions; (b) there is association among competitors (mutual understanding of the game), compliance to game rules as posed by the game manufacturer or further developed by game competition organizers, and institutionalization of gaming norms to allow for seamless tournament and individual game competition; and (c) there is evident contest among gaming participants. ${ }^{39}$

\section{The Slusher Test}

Howard Slusher also outlined several prominent features found in sport. ${ }^{40}$ Slusher noted that rules play an important role in determining what constitutes a sport: "The rules not only must create and regulate a given contest, but they must do so in a manner that makes it 'appealing' to the intended audience." ${ }^{11}$ Slusher further noted that organized sport has had a historical relationship to academics. ${ }^{42}$ Davis articulated that there is ongoing debate as to whether sports law exists or if, instead, the field should be more accurately titled sports and the law. ${ }^{43}$ Davis noted that the process by which fields become recognized as unique is an inexact science; much like the debate surrounding the existence of sports law as a unique field, there is debate surrounding the "sportiness" of esports. ${ }^{44}$ Slusher argued that a defining feature of sport is the reason for participation, suggesting that sport serves an "unfulfilled need for activity." ${ }^{5}$ Slusher noted three criteria for determining when an activity qualifies as a sport: rules for the creation of the game, whether the game is appealing to an audience, and whether it fulfills a human need for activity. ${ }^{46}$ Esports arguably fulfill 
all of Slusher's criteria in that games are undoubtedly guided by rules, not only rules for play but also rules of computer engineering, which dictate player actions. The appeal of esports to an audience can be seen in comparison to other sporting events; Hollist noted that the 2013 NBA Finals had 26.3 million viewers and the 2013 Bowl Championship Series (BCS) National Championship had 26.4 million viewers, whereas the 2013 League of Legends Season 3 World Championship had 32 million viewers. ${ }^{47}$ Slusher noted that the human need for activity "is so basic to human existence that not even language can bring it to the surface." 48 It has been argued that dance satisfies the human need for activity; however, it is possible that the defining features of human activity may be culturally subjective. ${ }^{49}$ While the playing of video games may not appear to have the same level of activity as some traditional sports, the stimulation of video games undoubtedly fulfills a need for activity among at least some esports participants. ${ }^{50}$

\section{The Michelman Test}

Michelman supports the proposition that a game's classification is dependent on a "public perception" of the activity. ${ }^{51}$ The Michelman test for determining whether an activity is a sport is the most straightforward, yet equally subjective. Potentially complicating the analysis is determining who makes up the public. ${ }^{52} \mathrm{~A}$ Reddit poll found that fewer than $30 \%$ of people surveyed in 2014 considered competitive video gaming to be a sport. ${ }^{53}$ Despite the negative view held by Reddit respondents, ESPN, "the worldwide leader in sports broadcasting," has begun coverage of esports, possibly suggesting that the viewing public may consider esports along the same lines as ESPN's other programming both on television and online. ${ }^{54}$ The public perception test, while likely the most subjective, may also be the most likely to exist in a state of constant temporal flux.

\section{The Wasserman Test}

In an analysis of cheerleading, Cassman highlighted the wide variety of interpretations for what constitutes a sport. ${ }^{55}$ Cassman observed that a dictionary definition required the activity to be athletic and necessitating "skill or physical prowess." 56 Cassman noted that law professor Howard Wasserman cited four elements present in a sport: "(1) large motor skills, (2) simple machines only, (3) objective scoring or at least the possibility of determining a winner by something other than subjective judging, and (4) competition among contestants." ${ }^{57}$ It is unlikely that any of the current forms of major esport contests rely on the use of gross motor skills; rather, the contestants undoubtedly rely on fine motor skills. Absent a virtual reality-style event, it is unlikely that most esports would satisfy the first prong of Wasserman's test. Similarly, it is unlikely that the gaming computers utilized by esports competitors could be classified as simple machines. The technology that has infiltrated many pieces of sports equipment, from biking and auto racing to football, likely renders spurious the idea that sport be restricted to the use of simple machines. The third Wasserman requirement is objective scoring - this feature is undoubtedly present in most, if not all, esports as participants are guided by the rules established by computer code; absent manipulation, scoring would likely be classified as objective. ${ }^{58}$ Finally, as noted previously, esports are competitions among both individuals 
and teams, and, as such, they likely satisfy the requirement of competition among participants under the fourth prong of the Wasserman test. ${ }^{59}$

\section{The Lakier Free Speech Test}

Assuming that esports can be characterized as sport, federal and state regulation would apply. Under its enumerated powers and the Commerce Clause, the federal government could then legislate esports as interstate commerce. ${ }^{60}$ State governments may regulate esports as well, under state police powers, should a sport qualification be attributed to esports. However, in this analysis, a concomitant question arises: might esports and competitive gaming be considered an expressive activity, thus qualifying for First Amendment protection? For that matter, could certain sporting activities be rendered expressive content and preempt regulatory efforts by state or federal actors?

Lakier identifies a variety of historical arguments that have been made to distinguish sport from art- these arguments may be relevant to an analysis of whether esports are a form of performance art or a sport under the law. ${ }^{61}$ First, "sports are not expressive acts because they function to entertain rather than to educate or politicize." 62 Second, "there is something inherent in athletic activity that renders it inexpressive." 63 Third, "spectator sports are not entitled to First Amendment protection because they involve competitive activity." ${ }^{4}$ In Interactive Dig. Software Ass'n v. St. Louis County, the Eastern District of Missouri Court left unanswered the question of whether video games constituted expressive activity, noting only that the plaintiffs in the case failed to satisfy the court that their video games constituted expressive activity. ${ }^{65}$ Conversely, in Brown v. Entertainment Merchants Association (2011), the U.S. Supreme Court held that California legislation precluding the sale of violent video games to minors ran afoul of the First Amendment as both underinclusive and overinclusive:

As a means of protecting children from portrayals of violence, the legislation is seriously underinclusive .... [And] as a means of assisting concerned parents it is seriously overinclusive because it abridges the First Amendment rights of young people whose parents (and aunts and uncles) think violent video games are a harmless pastime. ${ }^{66}$

Lakier cited historical reasons that courts have used to distinguish spectator sport from protected First Amendment activities. ${ }^{67}$ Lakier noted courts have observed that sports have had a function to entertain rather than to educate or make a political statement; while Lakier debates this position, it is arguable that the primary purpose of most esports contests is to entertain rather than educate either players or spectators, and any political motivation attached to esports competition is likely ancillary to the entertainment objectives. ${ }^{68}$ The second feature historically identified as a rationale for First Amendment protection not being extended to spectator sport is that there is an inherent feature that renders the activity inexpressive. ${ }^{69}$ Lakier illustrated the argument by noting the contrasting treatment given to nude dancing and ballroom dancing_-nude dancing being an expressive activity, while ballroom dancing is not considered to convey the same level of expression. ${ }^{70}$ It is possible that some video games themselves may be entitled to First Amendment 
protection, whereas others are not. ${ }^{71}$ The third argument that has historically been leveled against extending First Amendment protection to spectator sport is that it is a competitive activity. ${ }^{72}$ Lakier contrasted ballet with football observing that while both are feats of skill, one is scripted and the other thrives on the uncertainty of outcome to entertain. ${ }^{73}$ While the merits of not extending First Amendment protections to competitive activity are debatable, it is likely that most esports and other sports are on the same side of an argument under the historical reasoning used by courts.

\section{The Guttman Test}

Jenny et al. recently noted that one challenge with classifying esports is that the term esports is a catchall word incorporating a variety of games and activities. ${ }^{74}$ The authors noted that Robert Morris University, in Illinois, recognizes esports as a varsity sport, and it has begun awarding scholarships to esports participants. ${ }^{75}$ According to an esports manager, the Department of Homeland Security will issue visas to esports players in the same class as those issued to other professional athletes. ${ }^{76}$ Jenny et al. examined the work of Guttman and noted it is necessary for a sport to include play, a set of rules, a determination of winner and loser, and "physical skills_-skillful and strategic use of one's body."77 The authors classify play as a "voluntary, intrinsically motivated activity," and argue that esports likely qualify as a form of play. ${ }^{78}$ As previously noted, esports are governed by the rules of a contest, but also by the rules established by game creators. ${ }^{79}$ Additionally, esports contests likely satisfy the requirement that a winner and loser be designated at the conclusion. According Jenny et al., the fourth characteristic required by Guttman is the subject of debate over the importance of physical movement and exactly how much use of one's body is necessary to meet the sport criteria. ${ }^{80}$ It is unclear how esports would be viewed should a court determine that a sport requires some form of physicality, but Jenny et al. argued that it was debatable whether esports contain sufficient physicality to satisfy the requirements of Guttman's test. ${ }^{81}$

\section{The Suits Test}

Additionally, Jenny et al. noted that Suits articulated five additional characteristics inherent in sport, including (i) having a defined set of rules, (ii) requiring skill, (iii) requiring physical skill, (iv) having a broad appeal, and (v) "hav[ing] achieved institutional stability where social institutions have rules which regulate it, stabilizing it as an important social practice." 82 Jenny et al. concluded that esports arguably meet the requirements of both Suits and Guttman, but there is likely to be debate over the amount of physical skill involved in esports and the level of institutional stability. ${ }^{83}$ The issues likely to be subject to debate include, as previously noted, whether the contests involve "physical skill" and whether esports have achieved institutional stability. The debate of whether esports have achieved institutional stability is complicated, because various esports titles exist and operate akin to different sports. ${ }^{84}$ Presently, there are a number of competing organizing groups that may lead to questions regarding whether the practice has achieved institutional stability. ${ }^{85}$ While esports are arguably approaching a point at which institutional stability will become necessary for continued growth, it appears uncertain whether that point has been reached. 


\section{The Jackiw Dictionary Test}

Jackiw, in 2014, highlighted the potential importance of video gaming constituting a sport under the Wire Act. ${ }^{86}$ Jackiw combined various dictionary definitions to define sport as "a physical activity for diversion, recreation, or pleasure, involving skill and competition." ${ }^{87}$ The various dictionary definitions can be combined into a four-element test for determining when an activity may be considered a sport: it is a physical activity; its goal is diversion, recreation, or pleasure; it involves skill; and it involves competition. ${ }^{88}$ As previously discussed, the amount of physical activity is likely to be the subject of debate for those seeking to classify esports as outside of the realm of sport. The other features identified by Jackiw appear to be present in most forms of esports; though possible that a player could engage in the activity for a reason other than diversion, recreation, or pleasure, it would appear unlikely. However, absent a consensus on whether there is sufficient physicality involved in esports, the activity is not clearly a sport by Jackiw's adapted definition.

\section{The US Code Conglomeration Test}

In addition to the aforementioned definitions and tests, several definitions in the US Code may provide assistance. For instance, 15 U.S.C. $§ 7801$, the Sports Agency and Responsibility and Trust Act, defines intercollegiate sport as follows: "[t]he term 'intercollegiate sport' means a sport played at the collegiate level for which eligibility requirements for participation by a student athlete are established by a national association for the promotion or regulation of college athletics." 89 Additionally, 18 U.S.C. $§ 224$, the Sports Bribery Act, offers a definition for sporting contest: "[t]he term 'sporting contest' means any contest in any sport, between individual contestants or teams of contestants (without regard to the amateur or professional status of the contestants therein), the occurrence of which is publicly announced before its occurrence." 90

21 U.S.C. $§ 2001$, the Designation of United States Anti-Doping Agency Act, which established the United States Anti-Doping Agency, defines amateur athletic competition: "[t]he term 'amateur athletic competition' means a contest, game, meet, match, tournament, regatta, or other event in which amateur athletes compete." 91 The definition of amateur athletic competition is supplemented by the definition of amateur athlete, defined as "an athlete who meets the eligibility standards established by the national governing body or paralympic sports organization for the sport in which the athlete competes." ${ }^{2}$ While the Anti-Doping Agency legislation does not provide a clear definition of sport, it is possible to garner that there must be some meeting of competitors, who satisfy eligibility standards, which are established by a national governing body.

By taking into account various sections of the US Code, it is possible that a court may one day adopt as a definition of sport the following requirements: eligibility and rules established by a governing association, contests between individuals or teams, and events held in front of and announced to the public in advance. ${ }^{93}$ As previously noted, there are presently a variety of governing bodies that establish both rules and eligibility for esports competitions; these organizations are likely akin to other governing associations such as the National Collegiate Athletic Association or the United States Tennis Association. ${ }^{94}$ There is little dispute that esports occur 
between both individuals and teams, depending on the contest and game rules. Additionally, the requirement that contests be announced to the public prior to beginning is likely satisfied for major esports events; however, it is acknowledged that in recreational settings, games may not be announced to the public prior to commencing. Esports likely satisfy the test for a sport if the US Code-derived test were to be used; however, given that no court has adopted such a test and there are no established requirements for what constitutes a sport, it is mere speculation that under current federal law esports would satisfy the requirements of a sport.

\section{The Biediger Tests}

In Biediger v. Quinnipiac University, the Second Circuit Court of Appeals addressed sport under Title IX regulations-in particular, whether competitive cheerleading members can be counted as varsity athletes for the purpose of complying with the legislation..$^{95}$ The Biediger plaintiffs argued that Quinnipiac University had improperly counted 30 athletes on the competitive cheerleading squad as varsity athletes for the purpose of determining the proportion of females afforded athletic opportunities, in comparison to the student body. ${ }^{96}$ The Second Circuit observed that competitive cheerleading at that time (2009-2010) did not yet qualify as a varsity sport. ${ }^{97}$ The Second Circuit noted that "the district court observed that competitive cheerleading was not yet recognized as a 'sport,' or even an 'emerging sport, by the NCAA." "98 Quinnipiac's cheerleading team did not qualify as a varsity sport because (1) there was no off-campus recruiting, (2) there existed no uniform set of rules that applied to competitive cheerleading, (3) the team competed against "a motley assortment of competitors," not only other varsity competitive cheerleading teams, and (4) the cheerleading team did not have a postseason that was of substantial similarity to regular season competitions. ${ }^{99}$ The Second Circuit accepted the findings of the District Court, but noted that, in time, competitive cheerleading may emerge as a recognized varsity sport. ${ }^{100}$

Quinnipiac had argued in its pleadings that the lower court had erroneously held that competitive cheerleading was not a sport. ${ }^{101}$ Quinnipiac argued that competitive cheerleading should be counted as a sport because the cheerleading team's "operating budget, benefits and services (e.g., equipment, medical treatment, study halls, community service opportunities, publicity), and coaching staff [were] administered by the athletics department, just like all other varsity teams."102 Additionally, Quinnipiac noted that athletes on the competitive cheerleading team received scholarships and were eligible for awards and "University-wide recognition."'103

In response, the Biediger plaintiffs argued that the district court had correctly interpreted the status of competitive cheerleading as falling outside of the scope of the definition of sport. ${ }^{104}$ The plaintiffs noted that prior to Title IX, most schools did not afford women the chance for athletic participation. ${ }^{105}$ The plaintiffs cited a 2000 OCR letter stating that "cheerleading and other like activities are extracurricular activities and are not considered sports."106 The plaintiffs further cited the 2000 letter as noting that some activities "require a considerable amount of athleticism, but not every athletic activity qualifies as a sport." 107 In support for the plaintiffs, the United States filed an amicus brief. ${ }^{108}$ The brief cited the district court, noting that "for an athletic opportunity to count under Title IX, it must be genuine, meaning that it must take place in the course of playing an actual 'sport' and it must allow 
an athlete to receive the same benefits and experiences that she would receive if she played on another established varsity squad." 109 The government cited the following as important for classification as a sport: program structure and administration, team preparation and competition (including practice opportunities, regular season competitive opportunities, and post-season events), and the primary purpose of the activity is "athletic competition at the intercollegiate varsity level." 110 In support of the plaintiffs, the National Women's Law Center argued that in its current form competitive cheerleading "does not rise to the level of varsity sport." ${ }^{111}$ The National Women's Law Center argued that competitive cheerleading "lacks the organization, competition, and benefits that other varsity sports provide." 112 The group noted that while "activities such as cheerleading, drill team, and danceline" possess athletic components, they are "extracurricular activities rather than sports." 113 The National Women's Law Center further noted that athleticism alone does not qualify an activity to be considered a sport for Title IX purposes. ${ }^{114}$

In reply, Quinnipiac University argued that emerging sports, such as competitive cheerleading, should not be held to the same recruiting standards as established "sports like basketball and football." 115 Quinnipiac further advanced the argument that the OCR guidance was outdated and the OCR should give latitude to emerging sports that increase participation opportunities for women. ${ }^{116}$ Quinnipiac noted that under the OCR letter dated April 11, 2000, there are five components to determine which activities are a sport under Title IX. ${ }^{117}$ While the application of the Biediger Title IX tests to an analysis of whether esports constitute a sport is not dispositive, the Biediger tests, in combination with other tests, may provide guidance for future judicial interpretation as to the status of esports.

In addition to the parties' arguments, the Biediger cheerleading case contained a variety of different third-party positions as to what elements constitute a sport for the purposes of Title IX. ${ }^{118}$ For instance, the American Association of Cheerleading Coaches argued that there were four elements: physical activity propelling or overcoming a mass through space, competing against an opponent, rules to determine a winner, and the primary purpose of the activity being a comparison of skills. ${ }^{119}$ Unlike other tests requiring physicality, the Cheerleading Coaches Association specifies that physical activity propels or overcomes a mass through space; it is likely that, while meeting the latter of the elements, esports does not satisfy the specificity of the physicality prong in the definition from the American Association of Cheerleading Coaches.

Quinnipiac cited a variety of elements derived from the OCR Dear Colleague Letter, noting that a sport should be recognized if it has an operating budget comparable to that of other team sports and athletes receive comparable benefits and services (including equipment, medical treatment, study halls, community service opportunities, coaching opportunities, recruitment opportunities, try-outs, eligibility, comparable practice times and frequency, and other competitive opportunities). ${ }^{120}$ Additionally, Quinnipiac argued that team selection should be based on athletic ability, the team competing during a defined season, the activity being administered by a governing body, the primary purpose of the competition being athletic activity, and athletes being able to receive recognition. ${ }^{121}$ Provided esports are considered an athletic activity, it is likely that they would satisfy the components that Quinnipiac advanced unsuccessfully in attempting to convince the Second Circuit Court of Appeals that cheerleading was a sport under the guidance of Title IX. ${ }^{122}$ 
In addition to the arguments of the parties and various interest groups, the United States also entered into the Biediger case by filing an amicus brief. ${ }^{123}$ The government argued that for a sport to be counted under Title IX, it was required that it allowed the athletes on the team to receive the same benefits as other athletes, had a comparable program structure and administration, had comparable preparation for and competition to other sports, had post-season events, and had athletic competition as the primary purpose. ${ }^{124}$ It is likely that esports would compare similarly to other sports on the first four elements articulated by the United States, as, unlike cheerleading, there is a comprehensive esports competition schedule and postseason. ${ }^{125}$ The most likely challenge to the factors identified by the United States would be an argument that the competition is not of an athletic variety; however, an interpretation that esports were not an athletic endeavor would render spurious that sports such as chess contain an athletic component. As a consequence, it is possible that esports would satisfy the factors identified by the government for components present in recognized sports under Title IX.

The determination of whether esports are a sport may well be determined by one of the aforementioned tests. However, it is also possible that a court may look to a different source, such as state law, as a potential guideline for addressing whether esports are a sport. ${ }^{126}$ Indeed, the recently concluded dispute in New York over the offering of mixed martial arts competitions within the state's borders serves as a meaningful example of the states' traditional role in regulating how activities are classified. ${ }^{127}$ Nevada is the state arguably at the most advanced stage in preparing to address esports at the state level. ${ }^{128}$ In Nevada, as a result of the process for determining gambling regulations being dependent on whether an activity is a sport or other event, which may or may not be tied to a sport (e.g. which college football player will win the Heisman Trophy), the state has taken a proactive role into investigating how esports should be classified. ${ }^{129}$ Washington State has also taken an interest in a derivative aspect of esports, "skin" betting, ${ }^{130}$ with the Washington State Gambling Commission ordering game maker Valve to cease facilitating gambling via virtual gun and knife "skins." ${ }^{31}$ Despite these early steps, no state has affirmatively taken a position on esports as sports. While the classification of esports as sport is important for a number of federal statutes, there is large breadth of federal laws that could potentially be implicated as esports continues to grow in the United States regardless of its status as a sport.

\section{Emerging Litigation}

The issue of whether esports are classified as sport is quite important. If esports are determined to be a sport, stakeholders will face a number of decisions that may shape the future of the leagues, as well as perceptions toward them, and executives will be forced to make difficult decisions regarding issues such as whether action should be taken against states regulating esports betting via the Professional and Amateur Sports Protection Act. ${ }^{132}$ League officials would also need to determine whether to seek assistance by the Department of Justice via the Wire Act ${ }^{133}$ to shut down the vast illegal gambling industry that has arguably fueled interest, but also brought allegations of corruption to the industry. ${ }^{134}$ In addition to concerns surrounding the gambling industry, the determination of esports as a sport may have Title IX implications, if educational institutions choose to officially sanction esports 
teams as institutionally sponsored activities. ${ }^{135}$ The interpretation of whether esports constitute a sport has a meaningful impact on the industry and could implicate multiple avenues of litigation. The first area of concern, as summarized in Table 2, is the potential invocation of various sport-specific statutes, which apply to various aspects of the esports field, including gambling, broadcasting, gender equity, and participant representation. ${ }^{136}$ In addition to the various sport-specific statutes that may present hurdles to sustained growth, the industry faces potential challenges in the areas of consumer protection statutes, intellectual property rights, and antitrust laws. The esports industry's growth has been at least aided by the attached gambling industry, and this area of litigation has gained media attention. ${ }^{137}$ As of August 29, 2016, four class action suits were filed by disgruntled gamers and their parents (when minors) involved in esports wagering. In addition, intellectual property claims recently surfaced against esports game developer Valve Corporation. ${ }^{138}$ However, a bounty of additional challenges to the unbridled growth of esports are possible and distinctly foreseeable.

The original lawsuit filed against Valve Corporation alleged that the makers of Counter-Strike: Global Offensive had violated a number of Connecticut state laws in addition to federal Racketeer Influenced and Corrupt Organizations (RICO) statutes, presupposing the predicate act of operating an illegal gambling business. ${ }^{139}$ Despite filing an amended complaint several days later, and a change of venue to Washington State, the McLeod complaints were dismissed on October 4, 2016. ${ }^{140}$ The Western District of Washington court noted that the Plaintiffs had failed to meet the standing requirements because they only suffered gambling losses. ${ }^{141}$ Additionally, state law gambling offenses failed to satisfy the predicate offense requirement of the federal RICO statute. ${ }^{142}$ As a result of the dismissal of the RICO claims, the court also dismissed the state law claims, citing a lack of subject matter jurisdiction. ${ }^{143}$ The Reed and the C.B. cases were both disposed of by way of voluntary dismissal with prejudice by the Plaintiff fewer than 30 days after the cases were filed and prior to any briefs or motions to dismiss being filed. ${ }^{144}$

While the first wave of consumer lawsuits against Valve Corporation appear to have been weathered, there exists an ongoing intellectual property lawsuit against it, as well as a state gambling commission investigation against the company. ${ }^{145}$ The legal attention that has recently been focused on Valve is a small indication of the potential forthcoming federal litigation, should esports continue their expansion in the United States. As briefly illustrated in Table 2, the breadth of areas of law impacted by esports is meaningful, and at this nascent stage in the United States companies such as Valve, Activision Blizzard, and Riot Games would be well positioned to begin considering how to preemptively address issues that may be reasonably anticipated. If the daily fantasy sports industry is to provide an example, it appears that the strategy of proceeding on a state-by-state basis may be too costly of an endeavor (risking regulatory oversight and states' Attorneys General intervention on a variety of issues; for example, at the outset of controversy and calls for legislating this fledgling industry, daily fantasy companies merely argued whether their activity was gambling). ${ }^{146}$ It may be beneficial for these companies to adopt proactive initiatives, such as the implementation of best practices guidelines in order to demonstrate that the industry is capable of some level of self-regulation. ${ }^{147}$ In particular, specific organizations (such as the aforementioned gaming companies) receive heightened scrutiny as a result of their potential vulnerability to corruption, 


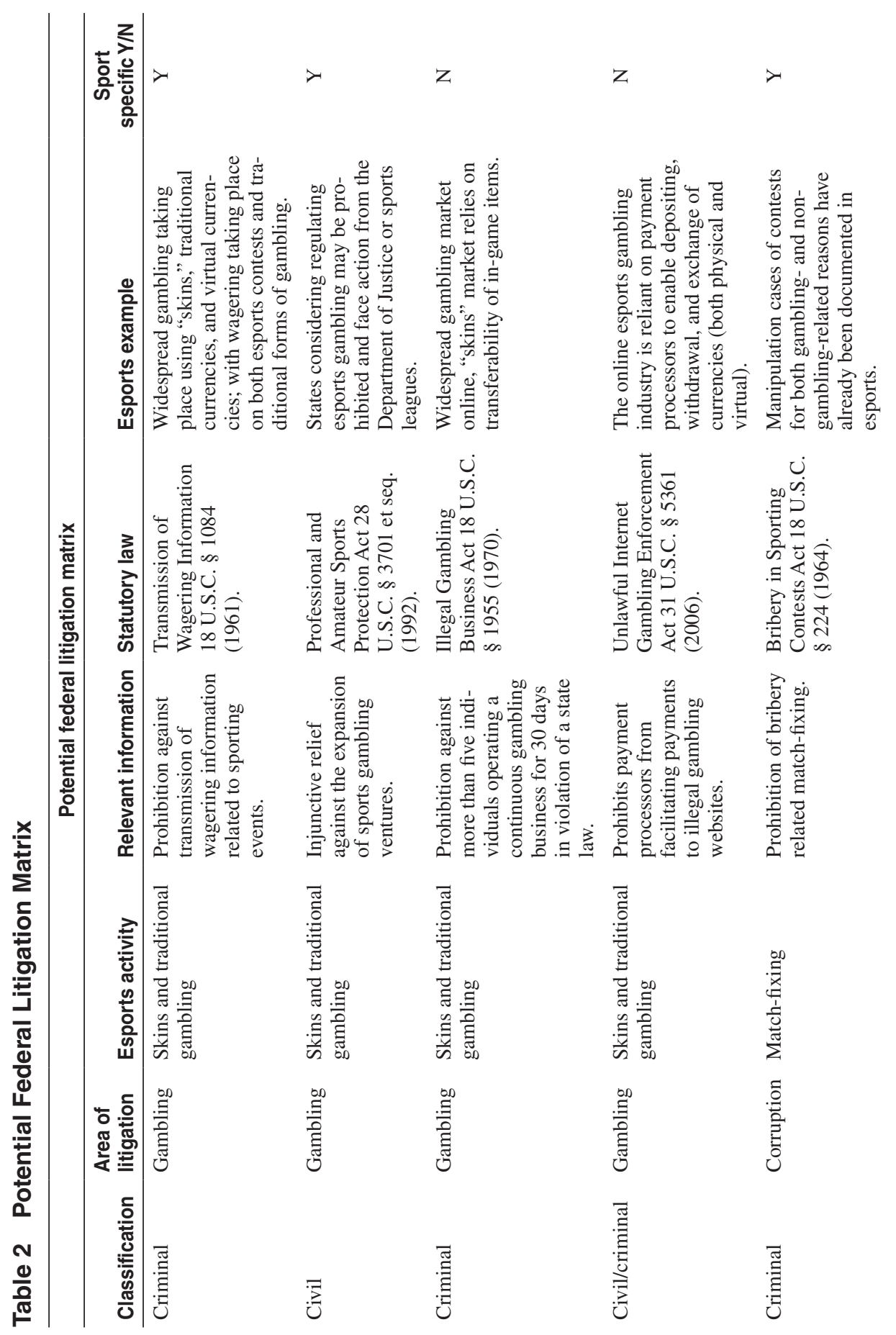




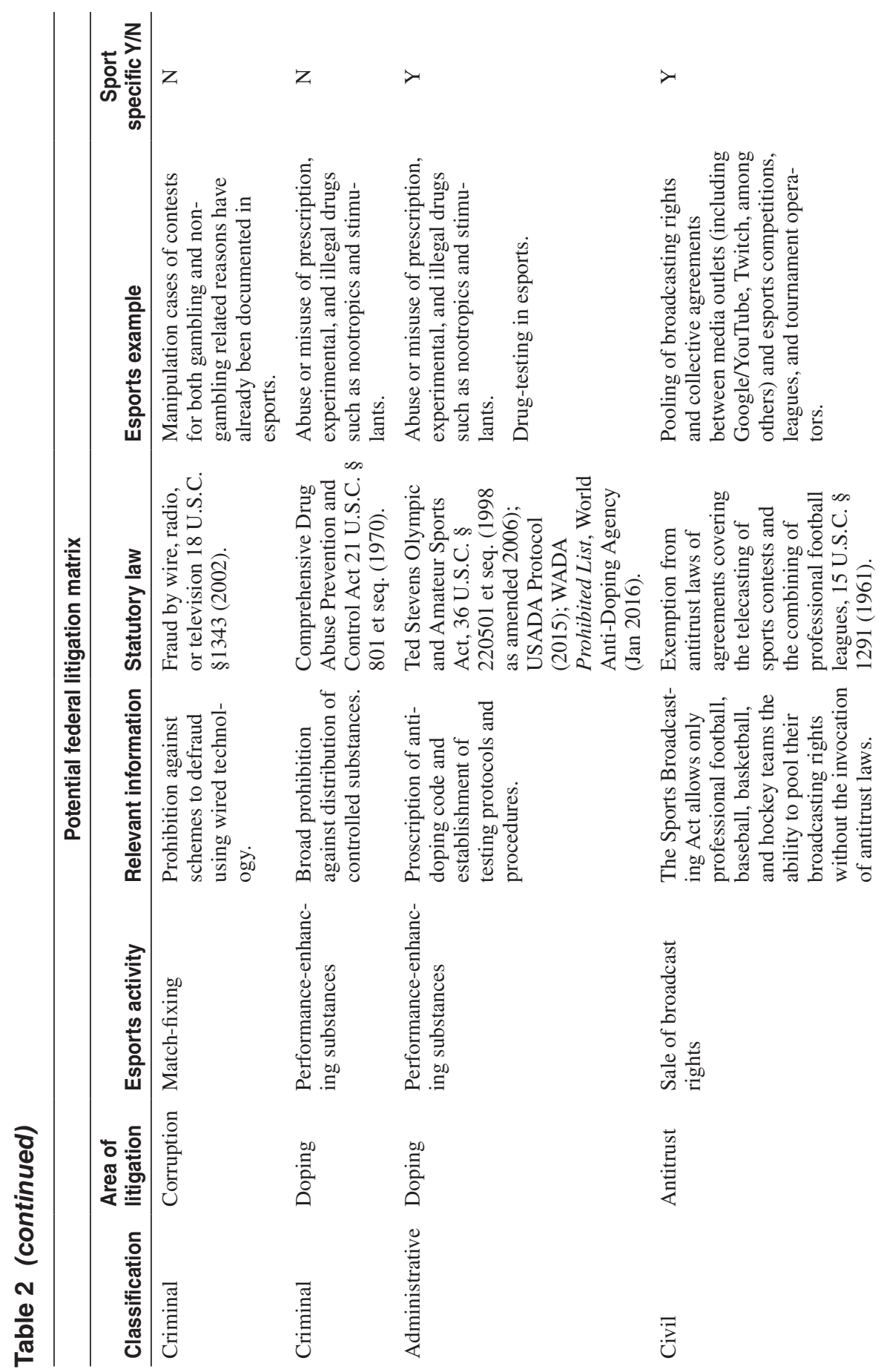




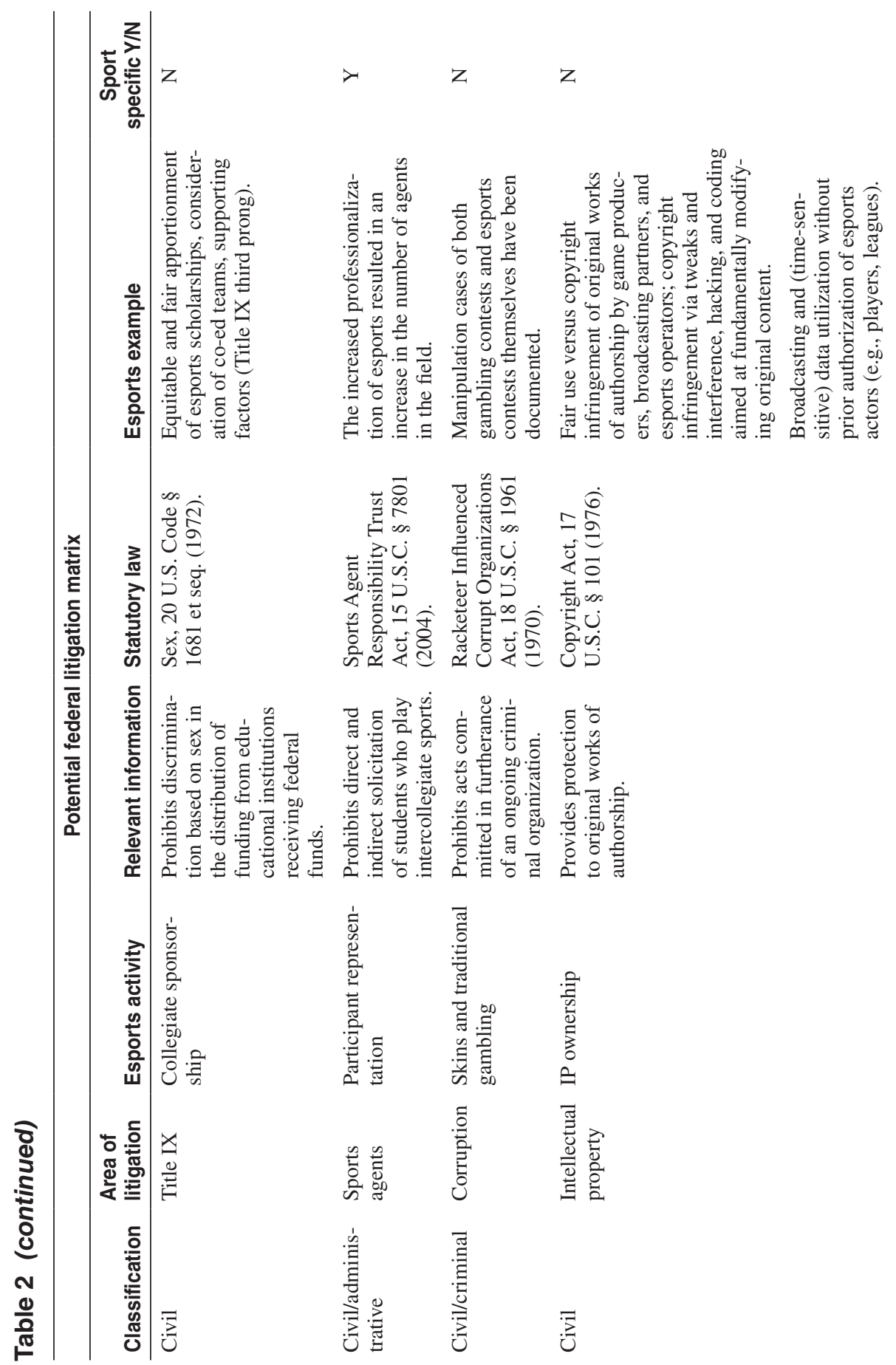




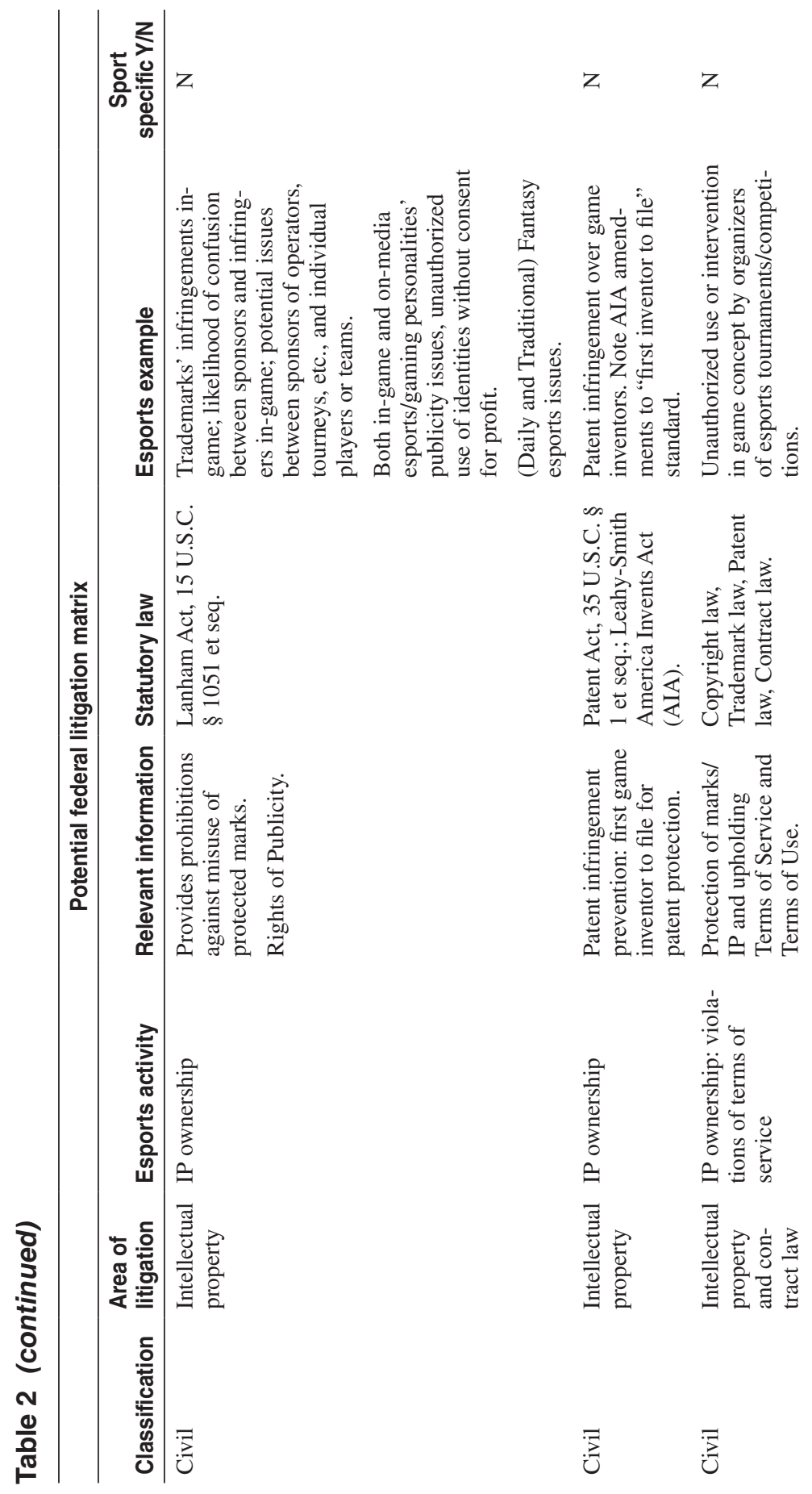




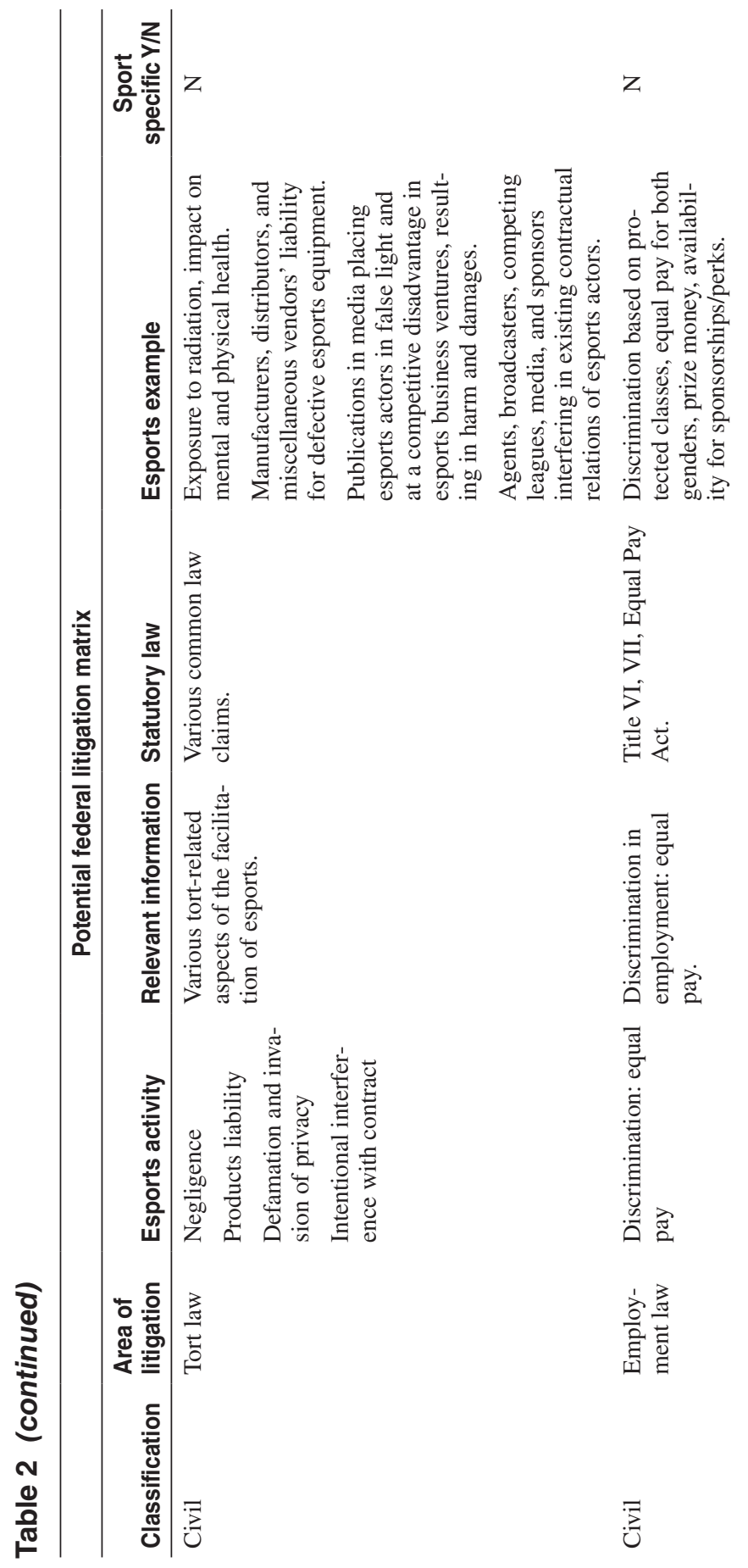




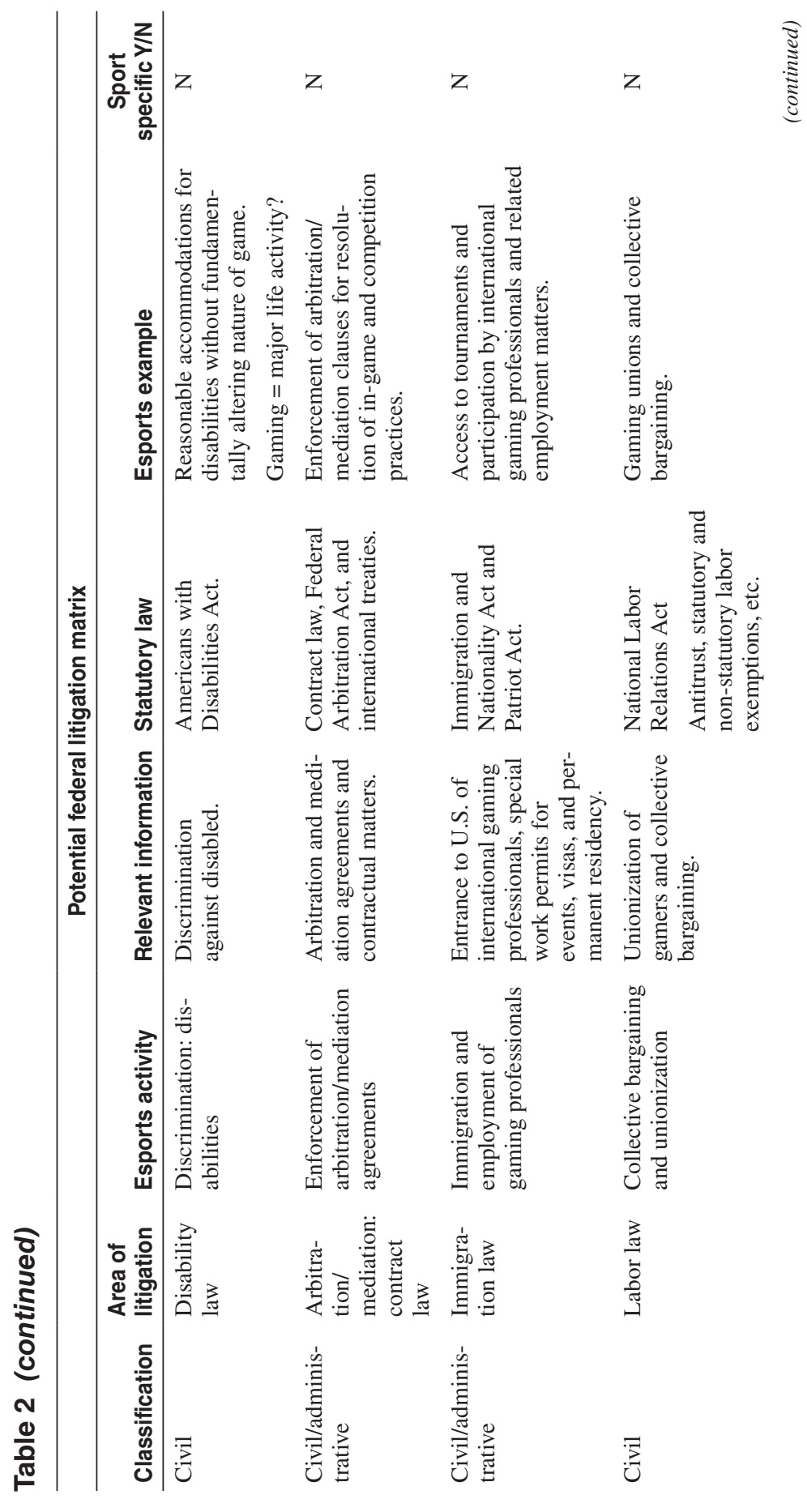




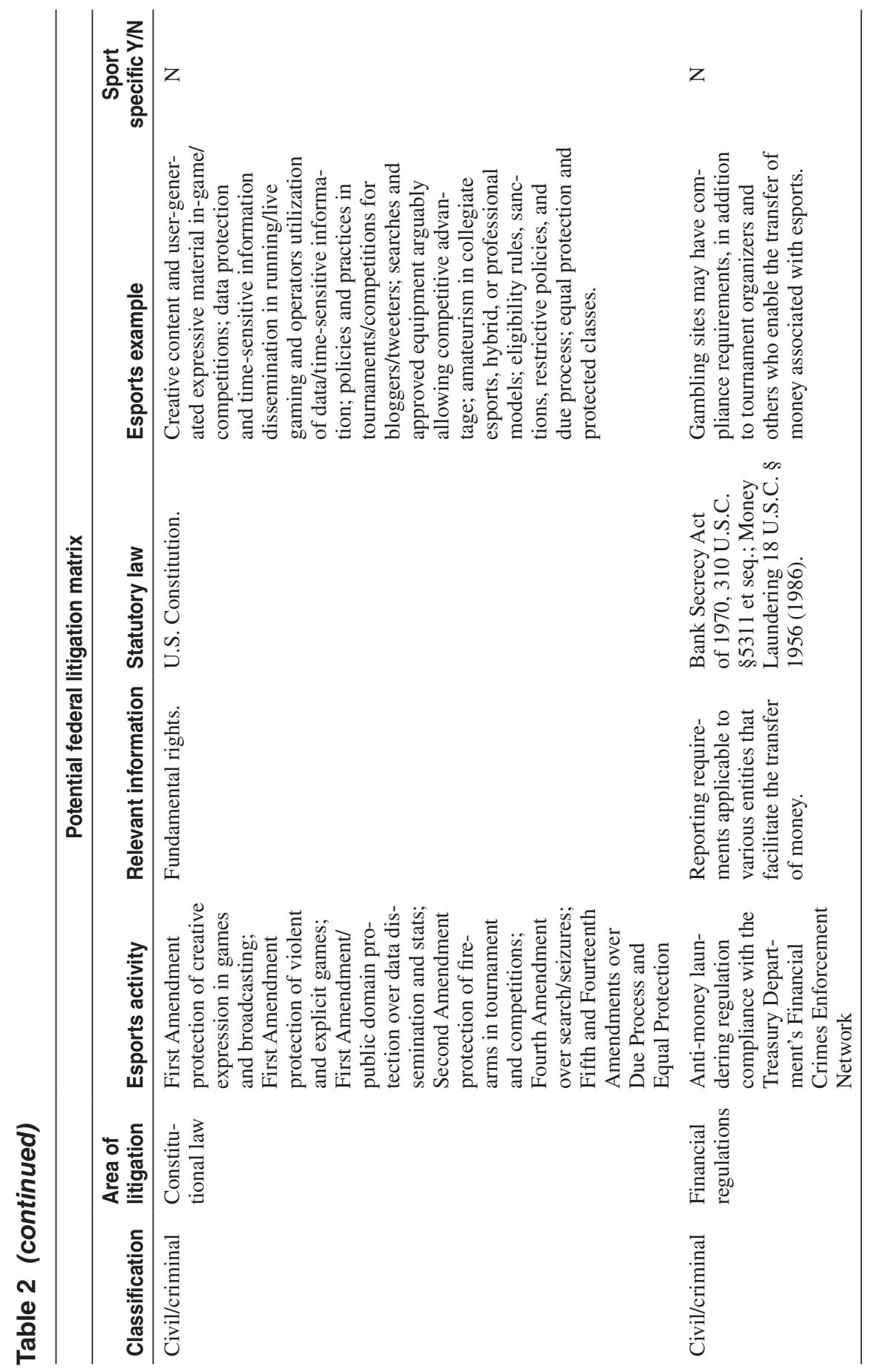


considering criminal elements are beginning to notice the lucrative esports market and take steps to capitalize on its growth. ${ }^{148}$ Hence, it would be beneficial for esports enterprises to implement procedures to avoid negative associations. ${ }^{149}$

\section{Conclusion}

The classification of esports as a sport would have a potentially significant impact on the industry in the form of increased exposure to certain litigation. ${ }^{150}$ While clarification may provide some certainty moving forward, it is speculative as to what impact clarity of status would provide to the average participant. It appears that a number of the organized leagues are beginning to function similarly to other sports leagues even without a proclamation that competitive video gaming is a sport. ${ }^{151}$ The development of esports as a form of mainstream entertainment is underway, and given the continued growth in investment from mainstream partners, it is likely that some of the identified areas of potential litigation will make their way to court in the coming years. ${ }^{152}$

If other sports and sport-related industries are to provide a lesson for the development and growth of esports, it would likely be that esports stakeholders should take proactive steps to demonstrate that they are capable of largely autonomous self-regulation. While it appears that the first wave of esports consumer lawsuits have been handled with relatively little fanfare, the connection between the esports game makers, developers, producers, and the derivative gambling industry is far closer than the relationship between traditional sports and the gambling industry, which frequently draws the interests of lawmakers. The close connection between some segments of the gambling industry and some game makers may create an added risk for the industry, particularly in the United States. Additionally, esports do not fit into traditional conceptualizations of sport because esports fans often actually play the same games that the professionals are playing-unlike most adults, who only consume sport through the various broadcast platforms and do not actively engage in the physical act of practicing and playing a sport, let alone competitively. In spite of esports differences from traditional sport, the industry's continued growth in the United States will likely depend on providing examples that are analogous to more traditional American sports and convincing lawmakers that esports can fit within the current governance model. Alternatively, esports actors will need to make a compelling case for sustainable self-regulation, to which the recent examples from the daily fantasy sports industry may prove insightful.

The distinct level of control over each game and the derivative aspects of the contests in esports may lead game makers to operate somewhat differently than other leagues within the "unique" sport industry. Aside from the aforementioned gambling and corruption issues, which are primarily addressed by the identified federal sport-specific statutes, esports executives will need to preemptively focus on antitrust matters, particularly as more competitors (and sponsors) enter an increasingly crowded esports space. ${ }^{153}$ Executive diligence and risk management will be two of the most important game maker tasks in the coming years, especially with the launch of ambitious new leagues such as Blizzard's Overwatch League, which will feature Overwatch teams in different cities across five continents. ${ }^{154}$ Various game manufacturers, event promoters, and team executives have begun an early push to increase the numbers of female professional gamers; unlike other leagues 
that have often launched ill-conceived female-friendly marketing ploys to attract consumers, esports stakeholders are seeking to expand actual participation of females at the highest levels of competition. ${ }^{155}$ Employment conditions and discrimination, contractual disputes, labor and collective bargaining and arbitration, licensing, player transfers and immigration are among several fronts, for which legal teams of esports stakeholder groups need to strategically prepare, possibly by utilizing or legislatively pursuing (e)sports-specific exemptions. The inevitable litigation, which will continue to emerge in the esports industry, will be one of the major factors that determines whether the activity continues to grow in popularity in the United States. Indeed, one of the factors that may be telling with respect to the growth and success of esports in the American market place is how stakeholders position the contests: are they a sport or are they an entertainment activity, like going to the movies? ${ }^{156}$ The answer is unknown at present, but over the coming years, likely through litigation in the flagged legal spheres, we will discover just what esports are.

\section{Notes}

1. See Nick Wingfield, Video Gamers Draw Real Crowds and Big Money, NY Times (Aug. 30, 2014), http://www.nytimes.com/2014/08/31/technology/esports-explosion-brings-opportunityriches-for-video-gamers.html?_r=0.

2. See Juho Hamari \& Max Sjöblom, What Is eSports and Why Do People Watch It?, Internet Research (Forthcoming, 2017), available at: http://papers.ssrn.com/sol3/papers.cfm?abstract_ id $=2686182 \&$ download=yes.

Esports may be organized according to specific genres of games (e.g. Multiplayer Online Battle Arenas, First-Person Shooters, Real Time Strategy or Sports). Id. at 3. Annually compiled by major media outlets are lists of the most popular esports titles, and the corresponding championships and prize money awarded therefrom. See e.g. Tyler Erzberger, The 2016 Top-10 eSports Draft, ESPN Sports (June 27, 2016), http://www.espn.com/esports/story/_id/16454680/the-2016-top10-esports-draft; John Gaudiosi, These Are the Most Popular Esports Games on Twitch, Fortune (April 6, 2016), http://fortune.com/2016/04/06/most-popular-esports-games-on-twitch/; Top Games Awarding Prize Money, E-sports earnings (November 9, 2016, 1:15 PM), http://www. esportsearnings.com/games.

3. See Paul Lee \& Duncan Stewart, Technology, Media \& Telecommunications Predictions, Deloitte (2016), available at: http://www2.deloitte.com/content/dam/Deloitte/global/Documents/ Technology-Media-Telecommunications/gx-tmt-prediction-2016-full-report.pdf.

4. Henry Young, Seven-Figure Salaries, Sold-Out Stadiums: Is Pro Video Gaming a Sport? CNN (May 31, 2016), http://edition.cnn.com/2016/05/31/sport/esports-is-professional-gaming-asport/. See also, Esports: How We Got to Here and What Comes Next, Leaders Report (September 2016), http://strivesponsorship.com/wp-content/uploads/2016/09/eSports-How-we-got-to-hereand-what-comes-next-Leaders-Special-Report.pdf

5. See Petr Parshakov \& Marina Zavertiaeva, Team Diversity and Performance in eSports (Working Paper), available at https://idlab.hse.ru/data/2016/01/25/1138706885/parshakov_ zavertieva_idlab_seminar_25_01_16.pdf.

6. For a discussion of issues relating to corruption in esports see generally Ben Fischer, New Group's Focus: Corruption in Esports, Sport Business General (May 9, 2016), http://www. sportsbusinessdaily.com/Journal/Issues/2016/05/09/Leagues-and-Governing-Bodies/Esportscorruption.aspx; for a discussion of issues of diversity in esports see Raynika Awotwi, Diversity in Esports: The Ongoing Struggle, CG MagOnline (Mar. 24, 2016), http://www.cgmagonline. com/2016/03/24/diversity-esports-remains-ongoing-effort/. 
7. See generally Broderick Chow, Eero Laine, and Claire Warden, Performance and Professional Wrestling, Routledge (2016); see also Tim Kail, The Art of Believability in Pro Wrestling, Work of Wrestling (May 12, 2016), http://www.workofwrestling.com/wowblog/the-art-of-believabilityin-pro-wrestling.

Popular video game titles may involve more of an artistic element than clear wins and losses columns as in traditional sport. For example, arguably the most popular video game of the mid 2010s, Minecraft, evolved into artistic competitions, in which preteens could win five-figure prizes, as well as a supporting industry of ancillary products, toys, even summer camps, comparable in duration, staffing, coaching oversight, pricing options, and weekly fees to popular sport camps. See e.g. Amy Kuperinsky, National Minecraft Tournament Invades N.J.; Who Will Win \$15K Scholarship? NJ.COM (March 07, 2016 1:15 PM), http://www.nj.com/entertainment/index. ssf/2016/03/super_league_minecraft_galactic_mission_movie_thea.html. See also Keith Nelson, Fifth Grader Wins the First Ever National Minecraft Tournament, Digital Trends.com (December 21, 2015 10:44AM), http://www.digitaltrends.com/gaming/minecraft-ten-years-old-microsoft/. See also https://www.idtech.com/minecraft-summer-camps/. See also https://www.techtrep.com/ minecraft-summer-camp/. For the creative aspect of video gaming and legal issues, see generally Greg Lastowka \& Dan Hunter, The Laws of Virtual Worlds (Working Paper), available at: http:// papers.ssrn.com/sol3/papers.cfm?abstract_id=402860. See also Greg Lastowka, Minecraft as Web 2.0: Amateur Creativity \& Digital Games (Working Paper), available at: http://papers.ssrn. com/sol3/papers.cfm?abstract-id=1939241.

8. See Young supra n. 4. In one sense skill-based competitive gaming may be more challenging for esports participants, considering they may have to develop new skills depending on game trends and evolving competitions. See, e.g. Tom Pitt, Professional Video Gaming Is a Uniquely Demanding Sport. We Need More Than a Drugs Crackdown to Fix It, Independent (Aug. 18, 2015), http://www.independent.co.uk/voices/professional-video-gaming-is-a-uniquely-demanding-sportwe-need-more-than-a-drugs-crackdown-to-fix-10460201.html.

9. See Martin D. Owens, What's in a Name? eSports, Betting, and Gaming Law, 20 Gaming L. Rev. \& Econ. 567 (2016).

10. Dennis Coates \& Petr Parshakov, Team vs. Individual Tournaments: Evidence from Prize Structure in eSports 1-20, 4 (Working Paper WP BRP 138/EC/2016), citing Michael Wagner, On the Scientific Relevance of eSports, proceeding of the 2006 International Conference on Internet Computing and Conference on Computer Game Development 436-440 (2006).

11. Hamari \& Sjöblom supra n. 2, at 2.

12. Id.

13. Elliot Hewitt, Will eSports Ever Become Widely Accepted as Official Sports and How Will They Affect the Way We Entertain Ourselves If They Do?, In Jamie Sharpe \& Richard Self eds., Computers for Everyone (1 ${ }^{\text {st }}$ Ed. 2014), available at: http://computing.derby.ac.uk/ojs/index.php/ c4e/article/view/90/67.

14. Id. at 81 .

15. Id.

16. Hewitt cites StarCraft II and League of Legends as games that are at the cutting edge of the esports market. See id.

17. Id.

18. Joao Pedro Brito Cicio de Carvalho, Business Models in Professional Electronic Sports Teams 1-139, 2 (Dissertation 2015).

19. Id.

20. Id. at 22 .

21. Id. 25-26.

22. See Young, supra n. 4, at 13-15. 
23. See Marcus Carter \& Martin Gibbs, Esports in Eve Online: Skullduggery, Fair Play and Acceptability in an Unbounded Competition, In Proceedings of the Foundations of Digital Games 2013 Conference 47-54 (2013).

24. See Katherine E. Hollist, Time to Be Grown-Ups about Video Gaming: The Rising eSports Industry and the Need for Regulation, 57 AZ. L. REV. 823, 825 (2015).

25. Id. at 826 .

26. See e.g. Transmission of Wagering Information, 18 U.S.C. $\S 1084$ (1961); see also Professional and Amateur Sports Protection, 28 U.S.C. § 3701-04 (1992); see also Bribery in Sporting Contests, 18 U.S.C. § 224 (1964); see also Ted Stevens Olympic and Amateur Sports Act, 36 U.S.C. $\S 220501$ et seq.; see also Exemption from antitrust laws of agreements covering the telecasting of sports contests and the combining of professional football leagues, 15 U.S.C. § 1291 (1961); see also Sports Agent Responsibility Trust Act, 15 U.S.C. $§ 7801$ (2004). For more extensive discussion of the scope of sport-specific and non-sport-specific statutes see Table 2 infra.

27. In 1888, Congressional Representative Barnes Compton of Maryland requested that an amendment be added to a bill that would specifically prohibit pool-selling on "games of baseball" in the District of Columbia. The un-amended bill had sought to make it unlawful to "bet, gamble or make books and pools on the result of any kind, or on any election or contest of any kind." See 50 Cong. Rec. 1162 (1888) (Statement of Rep. Barnes Compton).

28. See Dionne Koller, Putting Public Law into "Private" Sport, 43 Pepperdine L. Rev. 681, 698-699 (2016). For an overview of state-level sport specific statutes related to safety regulations see John O. Spengler \& Brian P. Burkett, Sport Safety Statutes and Inherent Risk: A Comparison Study of Sport Specific Legislation, 11 J. Legal Aspects of Sport 135 (2001).

29. See Id. citing 15 U.S.C. $\S \S 6301-13$ (2012).

30. See Thomas A. Baker III, Editor's Note, 26 J. Legal Aspects of Sport 69 (2016).

31. 18 U.S.C. $\S 224$ (1964).

32. 18 U.S.C. $\S 1084$ (1961).

33. 28 U.S.C. $§ 3701-04$ (1992).

34. For a discussion of France and esports see generally France Esports (2016), http://www. france-esports.org/.

35. For an example of a memorandum opinion issued by the Department of Justice see Virginia A. Seitz, Whether Proposals by Illinois and New York to Use the Internet and Out-of-State Transaction Processors to Sell Lottery Tickets to In-State Adults Violate the Wire Act, Memorandum Opinion for the Assistant Attorney General, Criminal Division, U.S. Dept. Just. (Sept. 20, 2011), http://1. usa.gov/rB9Y6E. Indeed, the Department of Homeland Security's United States Citizenship and Immigration Services (USCIS) has issued P1 visas to a number of esports competitors, which are reserved for professional athletes, though this administrative decision would not represent a binding decision on judicial actors, and would not be dispositive of esports being sports. See Matt Dillon, An Esports Attorney Reviews the Visa Issues in Esports, Gamurs (Jan. 28, 2016), https:// gamurs.com/articles/an-esports-attorney-reviews-the-visa-issues-in-esports. Adding additional confusion even within the status of esports under the USCIS, certain esports competitors have been denied P1 visas by virtue of the game they play. See Joss Wood, White House Petition Response on Esports Team Visas Fails to Resolve the Issue, EsportsBettingReport (June 28, 2016 10:12 PM), http://www.esportsbettingreport.com/white-house-esports-p1-visa-response/.

36. Olympic Charter Rule 45, Sec. 3 (August 2, 2016); according to Rule 45 "Only sports which comply with the Olympic Charter and the World Anti-Doping Code are eligible to be in the programme." https://stillmed.olympic.org/media/Document\%20Library/ OlympicOrg/General/EN-Olympic-Charter.pdf\#_ga=1.8145847.446331155.1471927548. Evaluation items for events (and addition/elimination of sports) include 35 criteria segmented into 5 themes: Olympic Proposal, Value Added to the Olympic Movement, Institutional Matters 
[18/35 criteria, i.e. Year of Establishment of International Federation and its recognition by the IOC, Number of World Championships to date, Number of National Federations, Percentage of National Federations organizing National Championships, Gender Equality in Executive Board, Finance (e.g. share of income generated by marketing/promotions and share of expenditures allocated to development), Anti-Doping/Compliance with WADA Code, Court of Arbitration for Sport/ Compliance with CAS, Competition manipulation (rules combating competition fixing (emphasis added)), Code of Ethics, Medical Commission, Athletes' Health, Safety, and Security, et al.], Popularity, and Business Model; see https:/stillmed.olympic.org/media/Document\%20Library/ OlympicOrg/IOC/Who-We-Are/Commissions/Olympic-Programme/Olympic-programme-Hostcity-proposal-Evaluation-criteria.pdf\#_ga=1.48426787.446331155.1471927548.

37. See James A. R. Nafziger, International Sport Law, Transnational Publishers (1988).

38. Id. citing Günther Lüschen, Cooperation, Association, and Contest, 14 J. Conflict Resol. 21 (1970).

39. See Young supra n. 4.

40. See Howard S. Slusher, Sport: A Philosophical Perspective, 38 L. \& Contemp. Probs. 129 (1973).

41. Id. at 129 .

42. Id. at $130-131$.

43. See Timothy Davis, What Is Sports Law?, 11 Marq. Sports L. Rev. 211 (2000).

44. Id. at 217-218. Davis quotes Gardiner who stated "[t]he process by which legal areas are identified, constituted and named is a complex one and often to some extent arbitrary. There is no official recognition procedure. It is a process of legal practitioners and academics recognizing the growing application of the law to a new area of social life." See id. at 218 quoting Simon Gardiner, et al. Sports Law, Routledge at 73 (1998).

45. See Slusher supra n. 40, at 132.

46. Id.

47. See Hollist supra n. 24, at 827.

48. See Slusher supra n. 40, at 132 .

49. Id.

50. At the professional level esports competitors prepare for esports competitions on a near continuous basis. One American former esports professional described Korean professionals as practicing " 25 hours a day," noting that some professionals seem to spend every waking hour honing their craft. See Harrison Jacobs, Here's the Insane Training Schedule of a 20-Something Professional Gamer, Business Insider (May 11, 2015 1:05 PM), http://www.businessinsider. com/pro-gamers-explain-the-insane-training-regimen-they-use-to-stay-on-top-2015-5. Both professional gamers and researchers have recently commented that there is a need for physical activity in esports. See Jake Middleton, Michael O'Dell of Team Dignitas On Fitness In eSports and The Importance of Fitness For eSports Players, Esports Performance Lab (September 27, 2016), http://www.esportsperformancelab.com/2016/09/27/michael-odell-of-team-dignitas-onfitness-in-esports/ and http://www.esportsperformancelab.com/2016/09/27/the-importance-offitness-for-esports-players/

51. See Frank I. Michelman, Adjudication as Sport: Rhetoric Astray? 38 Osgoode Hall L. J. 583,585 (2000).

52. For general discussion regarding defining the reasonable person standard, see Warren F. Schwartz, Objective and Subjective Standards of Negligence: Defining the Reasonable Person to Induce Optimal Care and Optimal Populations of Injurers and Victims, 78 Geo. L. J. 241 (1989).

53. See James Dator, This Chart Will Help You Answer "Is It A Sport?" SBNation (Aug. 19, 2014 8:43AM), http://www.sbnation.com/lookit/2014/8/19/6044393/ 
is-it-a-sport-chart-nascar-bowling-ultimate-frisbee. A Reddit poll is not conducted under scientific conditions and we do not suggest that the findings of the poll are generalizable or even accurate; reference to the poll is for illustration purposes only.

54. See Kristie Chong Adler, ESPN.com Launches New Esports Vertical Covering the World of Competitive Gaming, ESPN Media Zone (Jan. 14, 2016), http://espnmediazone.com/us/pressreleases/2016/01/espn-com-launches-new-esports-vertical-covering-the-world-of-competitivegaming/.

55. See Ashlee A. Cassman, Bring It On! Cheerleading vs. Title IX: Could Cheerleading Ever Be Considered an Athletic Opportunity Under Title IX, and if So, What Implications Would That Have on University Compliance?, 17 Sports L. J. 245 (2010).

56. Id. at 247 citing Sport, Dictionary.com, http://www.dictionary.com/browse/sport.

57. Id. citing Posting of Howard Wasserman to Sports Law Blog, http;//sports-law.blogspot. com/2008 12_01archive.html (Dec. 28, 2008, 23:05 EST).

58. For instance, in Counter-Strike:Global Offensive, points are awarded depending on player actions towards accomplishing the team goal. See CS:GO Competitive Scoring System, CounterStrike Net (June 23, 2015), http://www.counterstrike.net/csgo-resources/csgo-competitivescoring-system/.

59. See generally Hollist supra $\mathrm{n}$. 24; see also Ken Drazen, What Does It Take for an eSports Team to Win?, RedBull (Nov. 27, 2015), http://www.redbull.com/my/en/esports/stories/1331762143947/ what-does-it-take-for-an-esports-team-to-win.

60. US Const Art I, $\S 8, \mathrm{cl} 3$ (authorizing Congress "[t]o regulate Commerce with foreign Nations, and among the several States ...")

61. See Genevieve Lakier, Sport As Speech, 16 U.Pa. J. Const. L. 1109 (2014).

62. Id. at 1121 .

63. Id. at 1122 .

64. Id. at 1123 .

65. 200 F. Supp. 2d 1126, 1141 (E.D. Mo. 2002). See also Nathan Phillips, Interactive Digital Software Ass'n v. St. Louis County: The First Amendment and Minors' Access to Violent Video Games, 19 Berkeley Tech. L. J. 585 (2004). In Brown v. Entertainment Merchants Association, the U.S. Supreme Court, in a 7-2 decision, affirmed a Ninth Circuit ruling in favor of the video game industry striking a California law, which preempted the sale or rental of violent video games to minors. 131 S. Ct. 2729 (2011).

66. See Brown supra n. 66, at 2742 .

67. See Lakier supra n. 62.

68. See id. at 1121-1122.

69. Id. at 1122 .

70. Id.

71. See e.g. concurring opinion by Justice Alito in Brown differentiating between expressive (and vivid) content in literature and violent video games, supra n. 66 at 2742-2746 (Alito concurring). Justice Alito therein posits that the majority used a broad (First Amendment protection) brush for all expressive content, without regard to its nature; he frames his position based on the argument that ". . . only an extraordinarily imaginative reader who reads a description of a killing in a literary work will experience that event as vividly as he might if he played the role of the killer in a video game." Thus, he concludes that ". . . the experience of playing a video game may be quite different from . . . reading a book, listening to a radio broadcast, or viewing a movie." Id. at 2745-2746. In response, the majority held: "Reading Dante is unquestionably more cultured and intellectually edifying than playing Mortal Kombat. But these cultural and intellectual differences are not constitutional ones. Crudely violent video games, tawdry TV shows, and cheap 
novels and magazines are no less forms of speech than The Divine Comedy ..." Id. at 2737, n. 4. See also n. 128 et seq. and text infra, in respect to Mixed Martial Arts and the state of New York controversy in view of fights' inclusion in sport programming in NY.

72. See Lakier supra n. 62, at 1123-1124.

73. Id. at 1124 .

74. Seth E. Jenny et al., Virtual(ly) Athletes: Where eSports Fit within the Definition of "Sport", Quest (Online First 2016).

75. Id. at 2 .

76. Id. at 3 citing Paul Tassi, The U.S. Now Recognizes eSports Players as Professional Athletes, Forbes (July 14, 2013), http://www.forbes.com/sites/insertcoin/2013/07/14/the-u-s-nowrecognizes-esports-players-as-professional-athletes/\#41707c2c691d.

77. Id. at 5 citing Allan Guttman, From Ritual to Record: The Nature of Modern Sports, Columbia U. Press (1978).

78. Id. at 5 .

79. See Discussion supra n. 36 - n. 60 and accompanying text.

80. See Jenny et al. supra $\mathrm{n}$. 75, at 8-9.

81. Id. at 5 .

82. Id. citing Bernard Suits, The Elements of Sport in Ethics in Sport, Human Kinetics 9-29 (2007).

83. $I d$.

84. See e.g. Carvalho supra $\mathrm{n} .18$.

85. See Volker Stein \& Tobias M. Scholz, The Intercultural Challenge of Building the European eSports League for Video Gaming, In Case Studies in Intercultural Management: Achieving Synergy from Diversity, Eds. Christoph Barmeyer \& Peter Franklin (2014), available at: https:// www.wiwi.uni-siegen.de/pmg/lehre/dokumente_fuer_download/stein_scholz_case_2014.pdf.

86. See Suzanne Jackiw, Is Video Gaming a Sport?, 10 Sci. Tech. Law. 12 (2014). Jackiw noted that some multiplayer games where competitors are in multiple states may invoke the Wire Act. Id. at 15 .

87. Id. at 13 .

88. See Jackiw supra n. 87.

89. See Sports Agent Responsibility and Trust Act, 15 U.S.C. $\$ 7801$ (2004); For a thorough discussion of the intent and application of the Sports Agent Responsibility and Trust Act see John A. Gray, Sports Agent's Liability After SPARTA?, 6 Va. Sports \& Ent L. J. 141 (2006).

90. See Bribery in Sporting Contests, 18 U.S.C. $§ 224$ (1994).

91. See Designation of United States Anti-Doping Agency, 21 U.S.C. § 2001(a)(2) (2014).

92. Id. at (a)(3).

93. See Sports Agent Responsibility and Trust Act, 15 U.S.C. $§ 7801$ (2004); Bribery in Sporting Contests, 18 U.S.C. $\$ 224$ (1964); Designation of United States Anti-Doping Agency, 21 U.S.C. $\S 2001(\mathrm{a})(2)(2014)$.

94. See Carvalho supra $\mathrm{n}$. 18; see also Stein \& Scholz supra $\mathrm{n}$. 86; see also eGamingFederation (August 26, 2016), http://egfederation.com/.

95. 691 F.3d 85 (2d Cir. 2012). The relevant language of Title IX states: "No person in the United States shall, on the basis of sex, be excluded from participation in, be denied the benefits of, or be subjected to discrimination under any education program or activity receiving Federal financial assistance ...”20 U.S.C. § 1681 (a) (1972). In order to demonstrate compliance with Title IX academic institutions must satisfy a three prong test, which includes demonstrating that 
females are awarded proportionate opportunities to participate in athletics to their percentage of the student body; academic institutions must demonstrate a history of expanding opportunities for women to participate in athletics; and institutions must effectively accommodate the interests and abilities of female students on campus. See Title IX \& Issues, Women's Sports Foundation (2011), https://www.womenssportsfoundation.org/home/advocate/title-ix-and-issues/what-istitle-ix/standard-language-of-title-ix.

96. Id. at 91 .

97. Id. at 102-103.

98. Id. at 103. Conversely, several recent efforts have moved to create the competition structure and sponsorship of collegiate esports competitions, with a first major breakthrough being the Pac-12 Conference's announcement it will commence esports competitions during the 2016-2017 academic year. See Pac-12 Conference, Pac-12 Announces Series of Decisions out of End of Year Board Meetings, Pac-12 (May 24, 2016), http://pac-12.com/article/2016/05/24/pac-12-announcesseries-decisions-out-end-year-board-meetings.

99. Id. at 104-105.

100. $I d$. at 105 .

101. See Brief of the Appellant, Biediger v. Quinnipiac Univ., 691 F.3d 85 (2d Cir. Mar. 31, 2011).

102. $I d$. at $63-64$.

103. Id. at 64 .

104. See Brief of the Appellee, Biediger v. Quinnipiac Univ., 691 F.3d 85 (2d Cir. Aug. 31, 2011).

105. Id. at 35 .

106. Id. at 36 citing 2000 OCR Letters to Minnesota High School League re Cheer.

107. Id. citing 2000 OCR Letters to Minnesota High School League re Cheer.

108. See Brief of the United States as Amicus Curiae, Biediger v. Quinnipiac Univ., 691 F.3d 85 (2d Cir. Sep. 7, 2011).

109. $I d$. at 9.

110. $I d$. at $11-20$.

111. Brief of the National Women's Law Center et al., as Amicus Curiae, Biediger v. Quinnipiac Univ., 691 F.3d 85 (2d Cir. Sep. 7, 2011) at 12.

112. Id.

113. Id. at 13 .

114. Id. at 15 .

115. Reply Brief of the Appellant, Quinnipiac University, Biediger v. Quinnipiac Univ., 691 F.3d 85 (2d Cir. Sep. 21, 2011) at 9-10.

116. Id. at 11 .

117. Id. at 13; See also 2000 OCR Letters to Minnesota High School League re Cheer supra n. 107-108.

118. See Biediger supra n. 96.

119. See Debbie Pinckney, The Issue of Cheerleading as a Sports Need to Be Redefined, Auburn Pub. (Feb. 29, 2004), http://auburnpub.com/sports/the-issue-of-cheerleading-as-a-sport-needs-tobe/article_2f20c131-d4a2-58cc-9731-dd983c916e6f.html.

120. See Brief of Quinnipiac supra n. 102; see also Reply Brief of Quinnipiac supra n. 116.

121. $I d$.

122. See Biediger supra n. 96.

123. See Amicus Brief of the United States supra n. 109. 
124. $I d$.

125. See John Gaudiosi, Amazon's Twitch Launches "Counter-Strike” Esports Championship Series, Fortune (Apr. 6, 2016), http://fortune.com/2016/04/06/twitch-launches-counter-strikeesports-championship-series/; see also Pete Volk, 2016 League of Legends World Championship Will Be Held in North America, SBNation (Feb. 17, 2016), http://www.sbnation. com/2016/2/17/11031674/lol-worlds-season-6-2016-schedule-date-location; see also Charles Poladian, How to Buy the International Dota 2 Championship 2016 Tickets: On Sale Times for Midweek and Finals Options, IB Times (Apr. 72016 10:08 AM), http://www.ibtimes.com/howbuy-international-dota-2-championship-2016-tickets-sale-times-midweek-finals-2349910.

126. At least one commentator has noted that there is a strong possibility that the status of esports might play out on a state by state basis much like the legality of daily fantasy sports was addressed by individual states. See Sara Friedman, Beyond Nevada, E-Sports May Challenge PASPA Rules, GamblingCompliance (Oct. 19, 2016), https://gamblingcompliance.com/premium-content/ news_analysis/beyond-nevada-e-sports-may-challenge-paspa-rules.

127. Cruz noted that the New York prohibition on MMA stems from a law, which was passed prior to the widespread acceptance of the fighting contests. Amongst the arguments advanced by the MMA plaintiffs challenging the laws was the position that the activity was protected by the First Amendment. In an intriguing bit of irony to the argument that MMA is protected by the First Amendment, the Southern District of New York upheld existing precedent that supported the proposition that sport is not protected expression under the Constitution. See Jason J. Cruz, Sport and Spectacle: Should MMA Be Protected under the First Amendment? 17 U. Denv. Sports \& Ent. L. J. 63 (2015). See also Jones et al. v. Schneiderman, 888 F.Supp. 2d 421 (S.D.N.Y. 2012); see also Jones et al. v. Schneiderman, 974 F. Supp. 2d 322 (S.D.N.Y. 2013); see also Jones et al. v. Schneiderman, 101 F.Supp.3d 283 (S.D.N.Y. 2015); see also Dahlia Lithwick, First Amendment Smackdown: What Would the Founding Fathers Have Thought of Mixed Martial Arts?, Slate (Nov. 23, 2011 2:54 PM), http://www.slate.com/articles/news_and_politics/jurisprudence/2011/11/ is_there_a_first_amendment_right_to_beat_your_mma_opponent_senseless_html.

128. See Joss Wood, How Aggressively Will Las Vegas Embrace Esports Betting? It Depends on Whether or Not It's a Sport, EsportsBettingReport (May 16, 2016 8:11 PM), http://www. esportsbettingreport.com/esports-betting-likely-coming-soon-nevada/.

129. $I d$.

130. See infra $\mathrm{n} .135$ et seq. and accompanying text.

131. See Will Green, Valve Responds to Washington State Regulators: “We Do Not Facilitate Gambling," EsportsBettingReport (Oct. 18, 2016 9:25 AM), http://www.esportsbettingreport. com/valve-response-wsgc-skin-gambling/.

132. 28 U.S.C. $\$ 3701-04$ (1992). To date, neither the PAC-12 nor the NCAA have filed a PASPA lawsuit seeking to block Nevada from offering esports betting.

133. 18 U.S.C. $\S 1084$ (1961).

134. For an overview of the Wire Act's application see Ryan M. Rodenberg \& Anastasios Kaburakis, Legal \& Corruption Issues in Sports Gambling, 23 J. Legal Aspects of Sport 8, 10-14 (2013).

135. For an overview of litigation surrounding Title IX over the statute's first 35 years see Paul Anderson \& Barbara Osborne, A Historical Review of Title IX Litigation, $18 \mathrm{~J}$. Legal Aspects of Sport 127 (2008). The Pac-12 and several individual schools have begun to recognize esports as an area of interest for students; however, widespread acceptance and consistent organization, funding, and competition have not yet emerged for intercollegiate esports to likely qualify as a sport under the Biediger precedent. See Biediger Tests and Accompanying Footnotes supra n.96n.126. As with cheerleading, there does appear to be growing momentum on college campuses for esports, though this momentum is at least partially being driven by game developers. See Rachel Perry, Esports in Colleges: How Universities Are Bridging the Gap between Esports and 
Traditional Sports, Esports Betting Report (June 7, 2016), http://www.esportsbettingreport.com/ colleges-universities-integrating-esports/. As part of Blizzard's new professional Overwatch league, Blizzard has plans for a National Football League style player combine for amateur and collegiate amateur players to showcase their talents for professional teams. See Philip Kollar, Overwatch League Is Blizzard's Ambitious New Esports Org, Includes City-Based Teams, Polygon (Nov. 4 2016), http://www.polygon.com/2016/11/4/13511762/overwatch-league-is-blizzards-ambitiousnew-esports-org-includes-city.

136. For background on some of the corruption issues in esports see Mark Doman, Esports: Organized Crime Gangs a Threat to Future of Competitive Gaming, Integrity Commissioner Warns, ABC (Aug. 29, 2016 4:13 PM), http://www.abc.net.au/news/2016-08-30/organised-crimegangs-threatening-future-of-esports-esic-warns/7690708.

137. See Staff, Esports Betting-Overview of the Esports Gambling Vertical, Esports Betting Report (2016), http://www.legalsportsreport.com/esports-betting/.

138. See Compl. McLeod v. Valve Corporation, 3:16-cv-01018-AWT (D.Ct. June 23, 2016). On June 28 McLeod filed an Amended Complaint. See Amended Compl. McLeod v. Valve Corporation, 3:16-cv-01018-AWT (D.Ct. June 28, 2016). See also Compl. Reed v. Valve Corp., 2:16-cv04099-ES-JAD (D. N.J. July 7, 2016). See also Amended Compl. C.B. v. Valve Corporation, 0:16-cv-61561-BB (S.D. Fla. July 7, 2016). See also Compl. McLeod v. Valve Corporation, 2:16-CV-01227-JCC (W. Wash. Aug. 4, 2016). In an effort to see its gaming title(s) receive expanded interest from various demographics and its revenue-producing outlets grow, Valve introduced - in August 2013-its "Arms Deal Update," through which decorative weapons "skins" were offered for purchase, sale, trades, and even wagering via third party operators [e.g. Counter-Strike: Global Offensive (CS:GO) Lounge and OPSkins, in effect allowing for skins to serve as alternative means of currency.] Hence, a multi-billion-dollar para-economy was built and grew exponentially (and rapidly) due to the availability of gaming social media and parallel vendors' networks. See generally Eric Yu, The Start of It All: Skin Gambling, Unikrn (July 15, 2016), https://unikrn.com/news/the-start-of-it-all/. Coincidentally, Valve was sued by British Telecommunications (BT), represented by Proskauer Rose, a prominent New York City law firm. In the BT complaint, Proskauer attorneys build the case for patent infringement, arguing that certain features of Valve's "Steam" platform infringe various BT patents. See Compl. British Telecommunications PLC v. Valve Corporation, 1:99-MC-09999 (D. Del. July 28, 2016).

139. See Compl. McLeod v. Valve Corporation, 3:16-cv-01018-AWT (D. Ct. June 23, 2016).

140. See McLeod et al v. Valve Corporation, C16-1227-JCC (W.D. Wash. Oct. 4, 2016).

141. $I d$.

142. $I d$.

143. $I d$.

144. See Reed v. Valve Corp. et al., Notice of Dismissal without Prejudice Pursuant to F.R.C.P. 41(a)(1)(A)(i), 2:16-CV-04099-ES-JAD (D. N.J. Aug. 4, 2016). See also C.B., v. Valve Corp et al., Final Order of Dismissal, 0:16-cv-61561-BB (S.D. Fl. Aug. 5, 2016).

145. For a more detailed overview of the recently concluded consumer lawsuits against Valve Corporation see John T. Holden, Ryan M. Rodenberg \& Anastasios Kaburakis, Esports Corruption, Gambling, Doping, and Global Governance, Forthcoming Md. J. Int'1 L. (2017) available at https://papers.ssrn.com/sol3/papers.cfm?abstract_id=2831718. For discussion of the intellectual property lawsuit pending against Valve see supra n.139. For a more detailed examination of the Washington State Gambling Commission investigation see Colin Campbell, Valve Fires Back at Washington State Gambling Commission over CS:GO Betting, Polygon (Oct. 18, 2016), http://www.polygon.com/2016/10/18/13318326/valve-fires-back-at-washington-state-gamblingcommission-over-cs-go-betting.

146. For discussion of the purported financial difficulties facing the two major daily fantasy companies see Emmett Knowlton, One Year after Taking Over the Fantasy Football World, DraftKings and 
FanDuel Are Reportedly Running Out of Cash and Can't Pay Their Vendors, Business Insider (Oct. 24, 2016 1:18 PM), http://www.businessinsider.com/draftkings-and-fanduel-reportedly-runningout-of-cash-and-cant-make-payments-2016-10; see also Kevin Draper, Report: DraftKings and FanDuel Aren't Paying Vendors, Have Almost No Cash on Hand, Deadspin (Oct. 23, 2016 9:49 PM), http://deadspin.com/report-draftkings-and-fanduel-arent-paying-vendors-ha-1788131122. The two major daily fantasy companies announced in November 2016 that they would be merging over the coming year. See Joe Drape, DraftKings and FanDuel Agree to Merge Daily Fantasy Sports Operations, NY Times (Nov. 18, 2016), http://www.nytimes.com/2016/11/19/sports/ draftkings-fanduel-merger-fantasy-sports.html?_r=0. While still uncertain as to whether one or several rival esports leagues will emerge to dominate the market it is possible that some leagues may seek a merger either from a position of strength in an effort to control the marketplace, or from a position of weakness such as the purported position of the daily fantasy giants. Regardless, a merger that shrinks the amount of competition may trigger antitrust scrutiny from the Federal Trade Commission and/or the Department of Justice, in addition to potential exposure to private antitrust lawsuits from rivals. Indeed, there are signs that some esports leagues are taking protectionist actions by prohibiting players from participating in a competitor league's tournament. See Dean Takahashi, Counter-Strike: Global Offensive Esports Players and Owners Group Get into Dispute, VentureBeat (Dec. 23, 2016 3:18 PM), http://venturebeat.com/2016/12/23/counterstrike-global-offensive-esports-players-and-owners-group-get-into-dispute/.

147. See generally Young, supra n. 4.

148. See supra $\mathrm{n}$. 146. On October 5, 2016, the Washington State Gambling Commission issued a press release stating that the "Commission has notified Valve Corporation that it must immediately stop allowing the transfer of virtual weapons known as "skins" for gambling activities through the company's steam platform." Press Release-Valve Corporation Told to Stop Facilitating Gambling, Washington State Gambling Comm'n (Oct. 5, 2016), available at http://www.wsgc. wa.gov/publications/press-releases/valve-pressrelease.pdf. On October 17, 2016, the Gambling Commission issued a statement noting that Valve had missed their original deadline to respond. See Valve Corporation Update-New Information October 17, 2016, Washington State Gambling Comm'n (Oct. 17, 2016), available at http://www.wsgc.wa.gov/docs/10-2016-valve-update.pdf. On October 18, 2016, the Gambling Commission announced they had received a response from Valve. See Valve Corporation Update-New Information: October 18, 2016, Washington State Gambling Comm'n (Oct. 18, 2016), available at: http://www.wsgc.wa.gov/docs/10-18-2016-valve-update. pdf. In response to the Gambling Commission, Valve's representatives, addressing allegations of facilitating gambling sites through the transfer of "skins," stated: "If there is a specific criminal statute or regulation you believe Valve is violating please provide a citation. We are unaware of any such law that Steam or our games are violating." Valve's representatives continued: "We do not want to turn off the Steam services ... In-game items, Steam trading, and OpenID have substantial benefits for Steam customers and Steam game-making partners." See Letter from Liam Lavery, Legal Counsel Valve Corporation to David E. Trujillo, (Oct. 17, 2016), available at http://www. wsgc.wa.gov/docs/valve-letter-10-18-2016.pdf. The question of what the Washington State Gambling Commission or any other regulator will do next remains open, but despite various lawsuits and threats to skin gambling sites from Valve the skin gambling market continues to thrive.

149. See e.g. FIFA's plans for expanding into esports as was recently detailed in their "vision for the future." FIFA 2.0: The Vision for the Future, FIFA (Oct. 13, 2016).

150. See generally sport-specific statutes in Table 2 and accompanying footnotes.

151. For instance, leagues have implemented drug testing. See Luke Plunkettt, Pro Gaming League Will Drug Test Its Players, Kotaku (July 22, 2015 7:30 PM), http://kotaku.com/pro-gaming-leaguewill-drug-test-its-players-1719622064. Teams are also made up of ownership groups similar to other professional leagues. See Samuel Lingle, Meet the Immortals, the Venture Capital-Funded Esports Franchise That Bought Team 8's LCS Spot, The Daily Dot (Dec. 11, 2015 1:43 PM), http://www.dailydot.com/esports/immortals-team-8-noah-whinston-venture-capital/. 
152. See generally John Gaudiosi, What Investors Need to Know About eSports, Fortune (Dec. 10 2015, 10:55 AM), http://fortune.com/2015/12/10/investing-in-esports/.

153. Riot Games, the maker of League of Legends, banned two commentators from the 2016 League of Legends World Championships, one of whom was also banned from owning a team following a violation of Riot's rules governing ownership structure, player health and safety, and competitive integrity. See Whalen "Magus" Rozelle, Competitive Ruling: Renegades and TDK, LoL Esports (May 8, 2016), http://www.lolesports.com/en_US/articles/competitive-ruling-renegadesand-tdk; see also Jacob Wolf, Why MonteCristo and DoA Won't Cast at Worlds, ESPN (Sep. 16, 2016), http://www.espn.com/esports/story/_id/17496928/why-montecristo-doa-cast-worlds; see also Chris Tapsell, League of Legends eSports Controversy Continues as Riot Announces Sweeping Changes to Funding, EuroGamer (Sep. 23, 2016), http://www.eurogamer.net/articles/201609-23-lol-esports-drama-continues-as-riot-announce-sweeping-changes-to-funding; see also Zorine Te, Riot Games Responds to MonteCristo's Absence at Worlds, Yahoo (Oct. 28, 2016), https://esports.yahoo.com/riot-games-responds-to-montecristos-absence-at-worlds-004530765. html. This situation is distinctly reminiscent of early 1970s antitrust litigation in mainstream sports, e.g. in Levin and Lipton v. NBA et al., 385 F. Supp. 149 (S.D.N.Y. 1974) the plaintiffs were enjoined from acquiring the Boston Celtics, due to alleged connections to individuals undesirable to the majority of the NBA owners at the time. The court upheld the NBA's decision on valid non anti-competitive grounds, as "...the plaintiffs wanted to join with those unwilling to accept them, not to compete with them, but to be partners in the operation of a sports league for plaintiffs' profit." $I d$. at 152 . The current structure of many esports leagues may leave them potentially vulnerable to antitrust litigation given their organizational structures. In the coming months and years leagues will likely face a number of key decisions including matters such as minimum age rules, revenue sharing, and how to respond to player unionization efforts. See Liz Mullen, With League, Esports Entering New Labor Era, Sports Business Daily (Sep. 26, 2016), http://m.sportsbusinessdaily. com/Journal/Issues/2016/09/26/Labor-and-Agents/Esports-labor.aspx? .

154. The plan for the nascent Overwatch league has substantial promise; what has been proposed would be the first truly global club-based "esports" league. See Ben Barrett, Overwatch LeagueBlizzard's Plans, Leaked Info and Everything Else We Know, PC Games N (Dec. 22, 2016), http:// www.pcgamesn.com/overwatch/overwatch-league-teams-cities-dates.

155. See Gregory Schmidt, Esports Sees Profit in Attracting Female Gamers, NY Times (Dec. 21, 2016), http://www.nytimes.com/2016/12/21/technology/personaltech/video-game-makerstry-to-get-better-at-luring-women-to-esports.html?smid=tw-share\&_r=0. For discussion of the so called "pink it and shrink it" strategy of marketing to women employed by the NFL see Amy Hoidas, Marketing to Women: Why the "Pink It and Shrink It" Strategy Doesn't Always Work, Quality Logo Products (N.D.), https://www.qualitylogoproducts.com/blog/marketing-to-womenpink-it-shrink-it/. The NFL's "go pink" campaign has also been criticized for the authenticity of the leagues commitment to raising funds to fight cancer. See Marty Makary, The NFL's Pink Publicity Stunt Isn't about Fighting Cancer, Wall Street Journal (Sep. 30, 2016), http://www.wsj. com/articles/the-nfls-pink-publicity-stunt-isnt-about-fighting-cancer-1475275099/.

156. The comparison to going to the movies was made by DraftKings CEO Jason Robins who has struggled to find an apt comparison for his company's daily fantasy product that did not draw a connection to gambling. See Dustin Gouker, The Daily Fantasy Sports Analogy Game; or Why DFS Is Not like a Spelling Bee, US Poker (Jan. 5, 2016 10:40AM), http://www.uspoker.com/blog/ daily-fantasy-sports-analogies/13204/. 